\title{
A Drosophila rRNA gene located in euchromatin is active in transcription and nucleolus formation
}

\author{
Gary H. Karpen, ${ }^{1,3}$ John E. Schaefer, ${ }^{2}$ and Charles D. Laird ${ }^{1,3}$ \\ Departments of Genetics ${ }^{1}$ and Zoology; ${ }^{2}$ University of Washington, Seattle, Washington 98195 USA
}

\begin{abstract}
P-element transformants of a single rRNA gene (rDNA) were used to investigate the relationship between the organization of the nucleolus organizer (NO) and rDNA function in Drosophila melanogaster. In situ hybridization to rRNA in polytene nuclei of salivary glands demonstrated that an rRNA gene can be transcribed at a high rate when inserted into chromosomal sites other than the NO. Structures that resemble morphologically the endogenous nucleoli ('mininucleoli') were associated with four different euchromatic sites of rDNA insertion. Molecular analyses revealed that these mininucleoli contained both rRNA and an antigen specific to nucleoli. Phenotypes resulting from rDNA deficiencies were rescued partially by the presence of the transformed rDNA, indicating that the transcripts and mininucleoli associated with the rDNA insertion sites were functional. Thus, two conserved features of rDNA organization in eukaryotes, namely tandem repetition and heterochromatic localization, are not required for rRNA gene function. We conclude that 'nucleolar organizing activity' is an intrinsic property of the rDNA or its RNA products.
\end{abstract}

[Key Words: Nucleolus organizer; rDNA transcription; Drosophila; P-element transformation; bobbed mutant rescue; heterochromatin]

Received September 15, 1988; revised version accepted October 21, 1988.

The $18 \mathrm{~S}$ and $28 \mathrm{~S}$ rRNA genes (rDNAs) are unusual because both their clustering and chromosomal location have been conserved among eukaryotic species. rDNA is repeated tandemly in the nuclear genomes of the majority of eukaryotes (for review, see Long and Dawid 1980) and is associated (Ritossa and Spiegleman 1965) with a cytogenetic entity known as the secondary constriction, or nucleolus organizer (NO) (McClintock 1934). NOs are usually located in constitutive heterochromatin and/or reside in centromeric or telomeric chromosome regions (for references, see Lima-de-Faria 1976, 1983; Karpen 1987; G.H. Karpen and C.D. Laird, in prep.). An intriguing functional property of rDNA is its association with the nucleolus, a large nuclear organelle that is the site of numerous, critical steps in ribosome assembly and transport from the nucleus (Smetana and Busch 1974; Goessens 1984). rDNA is characterized by other interesting functional properties; a partial list includes high levels of RNA polymerase I-generated transcription (Miller and Beatty 1969; Laird et al. 1976; Roeder 1976), high levels of recombination (Petes 1980; Szostak and Wu 1980; Coen and Dover 1983; Voelkel-

${ }^{3}$ Corresponding author. Current address: Carnegie Institution of Washington, Department of Embryology, Baltimore, Maryland 21210 USA.

This paper is dedicated with fondness to the memory of Larry Sandler, in appreciation of his inspirational teaching, insightful research, and encouragement of human creativity.
Meiman et al. 1987), differential DNA replication in somatic cells (Spear and Gall 1973; Kunz et al. 1982) and germ cells (Brown and Dawid 1968; Macgregor 1982), and a possible role in sex chromosome pairing during Drosophila male meiosis (McKee and Lindsley 1987). In Drosophila, the total number of rDNA repeats in the genome does not reflect the number of functional rRNA genes. Up to $65 \%$ of the rRNA genes contain insertions of nonribosomal sequences in the $28 \mathrm{~S}$ coding region (for review, see Glover 1981). Insert-containing rRNA genes are transcribed at very low levels, if at all (Long and Dawid 1979), and make no apparent genetic contribution to viability or development (Franz and Kunz 1981; Long et al. 1981; Jamrich and Miller 1984).

Some observations suggest that rDNA functions such as transcriptional activity and nucleolus formation are not dependent on tandem repetition or heterochromatic localization. rRNA gene fragments containing the promoter region are active transcriptionally in in vitro transcription systems, amphibian oocyte injection assays, and transient expression assays using cultured cells (for review, see Sollner-Webb and Tower 1986; also see Grimaldi and Di Nocera 1986). However, the molecular analyses do not demonstrate that isolated rRNA genes can participate in their primary in vivo function, namely the production of ribosomes. Tandemly repeated, extrachromosomal rRNA genes are transcribed and asso- 
ciated with micronucleoli in the normal development and maturation of amphibian oocytes (Miller and Beatty 1969 |, indicating that in this system heterochromatic location is not necessary for rDNA transcription or function. Cytogenetic analyses in Drosophila melanogaster, however, indicate that the function of ribosomal genes may depend on the normal organization and location of the NO in the centromeric heterochromatin of the sex chromosomes. Chromosome rearrangements that move the $X$ centromeric heterochromatin and the NO (Ritossa and Spiegelman 1965) into euchromatin result in the partial suppression, or variegation, of rRNA transcription (Nix 1973) and nucleolus formation (Baker 1971; Hannah-Alava 1971; Hilliker and Appels 1982). Similarly, molecular studies suggest that tandem repetition of rDNA may play a role in optimizing rDNA transcription and thus may also be conserved because it promotes rDNA function (for review, see Baker and Platt 1986; Reeder et al. 1987). This hypothesis, however, has not been tested directly in vivo.

A separate but related question concerns our understanding of the exact relationship between the rDNA, the 'organizer,' and the control of nucleolus formation. Some cytogenetic experiments involving chromosome rearrangements (Durica and Krider 1978; Hilliker and Appels 1982) or laser microirradiation (Berns and Cheng 1971; Berns 1973) suggest that sequences extrinsic to the NO can control nucleolus formation. The results of more extensive cytogenetic experiments, however, strongly suggest that nucleolar-organizing activity is contained within the NO and may be an intrinsic property of the rDNA (McClintock 1934; Schalet 1969; Baker 1971; Hannah-Alava 1971; Givens and Phillips 1976; Hilliker and Appels 1982). One difficulty in using cytogenetic studies to identify the sequences responsible for nucleolus formation is that a complete molecular description of the NO and its surroundings has not been accomplished for these eukaryotes. In terms of molecular analyses, a central role for rDNA in nucleolus formation is supported by the observed association of the amplified, tandemly repeated, extrachromosomal rRNA genes with micronucleoli in amphibian oocytes (Miller and Beatty 1969). The role of tandem repetition in nucleolus formation is not addressed by these observations, however, and the relevance of this specialized system to the behavior of chromosomally located genes in somatic cells is unclear. In recent years, studies of chromosomally integrated rDNA-reporter gene constructs in cultured mammalian cells (Dhar et al. 1985; Vance et al. 1985 ) and in the yeast Saccharomyces cerevisiae (Elion and Warner 1986) have provided important information about rDNA expression and processing in vivo. None of these studies, however, used full-length ribosomal genes; therefore, function of the transcripts and the association of the rDNA with a nucleolus could not be monitored. Thus, a key question is left unresolved by these various cytogenetic and molecular analyses: Is nucleolus formation in somatic cells dependent on the presence of rDNA (or its products), non-rDNA sequences associated with or adjacent to the $\mathrm{NO}$, or a combination of the two?
An experimental approach allowing the manipulation of chromosomally located, defined rRNA genes should lead to a more complete understanding of how rDNA functions and nucleolus formation are controlled in vivo, in a developing organism with different cell types. We have used P-element-mediated transformation (Rubin and Spradling 1982; Spradling and Rubin 1982) to analyze the behavior of a single complete $D$. melanogaster rRNA gene when separated from the NO and the sex-chromosome centromeric heterochromatin and integrated at different sites in the genome. The spatial resolution afforded by polytene chromosomes allowed insert function to be analyzed without marking the gene with 'foreign' DNA sequences. We used in situ hybridization to rRNA and indirect immunofluorescence with an antibody that binds to Drosophila nucleoli to assess the transcriptional activity of the integrants in polytene chromosomes of salivary glands, as well as their ability to form nucleoli. In addition, complementation of partial deletions of the endogenous rDNA (bobbed mutations; Ritossa 1976) was used to evaluate the ability of the inserted rRNA genes to produce functional rRNA. We discuss the results of these experiments and their relevance to understanding the relationship between the organization of the NO and rDNA function.

\section{Results}

\section{Ribosomal,rosy transformants}

A single rRNA gene was inserted at a variety of euchromatic sites, as described in Materials and methods. All of the ribosomal,rosy (hereafter referred to as 'rib,ry') inserts contain the rosy ${ }^{+}$gene adjacent to a single rRNA (rDNA) gene, which consists of the ribosomal transcription unit (rDNA TU) and the $5^{\prime}$ - and 3 '-flanking spacers (Fig. 1). Each line contains a single rib,ry insert, as determined by Southern analysis and in situ hybridization (see Materials and methods); the number and letter following '[rib7]' in the name of the line [i.e., [rib7(23E)] and in genotype designations [i.e., [rib7] $\left.(23 \mathrm{E}) \mathrm{ry}^{+} / \mathrm{ScO} ; \mathrm{ry}^{506}\right]$

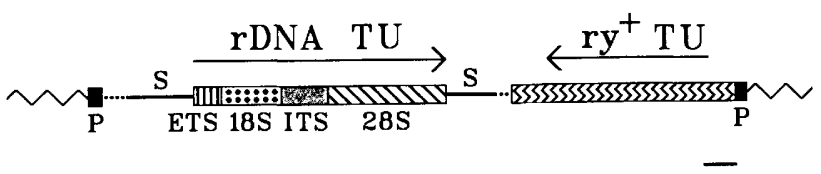

$1 \overline{\mathrm{kb}}$

Figure 1. Structure of the rib,ry inserts. The [rib7] integrants contain a rosy ${ }^{+}$transcription unit $\left(r y^{+} T U\right)$ adjacent to a single rRNA gene; these are flanked by the P-element ends $\{P \mid$. The rRNA gene contains spacers $(S)$ that flank an rDNA transcription unit $(r D N A T U)$. The $r D N A T U$ encodes the external transcribed spacer (ETS), the 18S rRNA (18S), the internal transcribed spacer (ITS), and the $28 \mathrm{~S}$ rRNA (28S). The dotted portion represents the pBR and bacteriophage $\lambda$ sequences present at the ends of the rDNA insert (see Materials and methods). Arrows indicate the direction of transcription for the $r D N A T U$ and the $r y^{+} T U$; for rDNA, the extent of transcription beyond the $28 \mathrm{~S}$ sequences is unknown (Tautz and Dover 1986). Zigzag line indicates the flanking chromosomal DNA. 
indicates the cytogenetic location of the inserted sequences, according to Bridges' (1935) salivary-gland polytene chromosome map (see Lefevre 1976).

\section{Transcriptional activity of $r D N A$ in the rib,ry integrants}

To determine whether a single rRNA gene could be expressed when placed in euchromatin, a method was needed to differentiate between the rRNA transcripts generated by the endogenous and the transformed genes. The transformant rRNA was not marked by inserting foreign DNA into the ribosomal transcription unit (rDNA TU) of the rib,ry plasmids (Fig. 1), because disruption of gene continuity could inhibit rDNA function. Instead, the banding pattern and size of polytene chromosomes were exploited to ask whether rRNA was present specifically at the sites of rib,ry insertion. Strand-specific RNA probes were hybridized to chromosome squashes that had not been RNased or denatured, under conditions that favored RNA/RNA (as opposed to RNA/DNA) hybrid formation (see Materials and methods). The level of hybridization under these conditions to rDNA, as opposed to rRNA, was assessed by comparing the signals generated by hybridization with noncomplementary (hybridizes to the DNA only) versus complementary (hybridizes to RNA and DNA) strand probes. These strand-specific probes are homologous to a specific portion of the external transcribed spacer (ETS, see Materials and methods and Fig. 1; ETS-C and ETS$\mathrm{NC}$ are used to indicate the complementary and noncomplementary strand probes, respectively|. Specificity of the probes for rRNA was assessed by comparing the number of grains present at particular chromosomal locations in strains with and without rib,ry insertions at that site and by monitoring the hybridization of probe to the endogenous nucleolus.

The results of the in situ hybridization to RNA experiments indicated that rRNA accumulated at euchromatic locations where single rRNA genes were inserted. After hybridization of complementary strand probes to chromosomes from four different transformed lines, significant numbers of grains were concentrated only at the nucleolus and at the sites of rib,ry insertion specific to that line (Table 1; Fig. 2). For example, grains were present frequently at 1A (3.78 grains/nucleus - day) but not at 94B $(0.022$ grains/nucleus.day) in strain [rib7](1A), whereas grains were observed often at 94B (1.26 grains/nucleus $\cdot$ day) but not at $1 \mathrm{~A}$ (0.035 grains/ nucleus - day in strain [rib7](94B). Figure 3a displays a summary of the data in Table 1, comparing total grain counts for the amount of ETS-C probe hybridization with and without insertion, for each site. Considerably more grains were observed at all four sites when a rib,ry insert was present. Note that the values for sites $1 \mathrm{~A}$, $23 \mathrm{E}, 68 \mathrm{BC}$, and 94B with no insertion present are less than or equal to the background levels of hybridization, measured at site 2B (included in the analysis as a no-insert control). Almost all of the signal that resulted from hybridization with the complementary strand probe was due to the presence of rRNA, and not rDNA, because hybridization with the noncomplementary strand probe yielded very few grains over the nucleolus (Fig. 2a) and the sites of rib,ry insertion (Table 1; ETS-C versus ETS$\mathrm{NC}$ ). Therefore, we conclude that single rRNA genes can accumulate rRNA when inserted outside the NO at all four different euchromatic locations analyzed.

\section{Nucleolar-like material is associated preferentially with the sites of rDNA insertion}

The preparations generated by in situ hybridization to rRNA in polytene chromosomes were also analyzed to determine whether nucleolar-like material was associated preferentially with the sites of rib,ry insertion. These squash preparations indicated that structures resembling the endogenous nucleolus, but physically separate from it, were associated with all four sites of rib,ry insertion analyzed. A high concentration of grains, and thus rRNA, appeared to be contained within a structure whose main body lies off the chromosome but is attached to it at the location of the rDNA insert. This was apparent especially for insertion at the tip of the $X$ lopen arrows, Fig. $4 a-c)$. Because these properties are shared with the endogenous nucleoli (solid arrows in Fig. 4b-e; Viinikka et al. 1971) and because the ectopic structures are generally smaller than the endogenous nucleolus, we will refer to these structures as 'mininucleoli' in further discussions of our results.

The terminal location of the 1A insertion site made it easy to identify structures that extended beyond the chromosome proper (Fig. $4 \mathrm{a}-\mathrm{c}$ ). The more proximal location of the three autosomal sites presented more difficulty in scoring for the presence or absence of a mininucleolus in some nuclei; structures at these sites often resembled 'doughnuts,' or large puffs, surrounding the chromosomes (Fig. 4d-f), rather than the 'lightbulb' shape of the mininucleoli at $1 \mathrm{~A}$ and the endogenous nucleolus. Control experiments indicated that the extrusion of grains from the chromosomes and into the doughnut-shaped structures at the autosomal rib,ry sites did not result solely from the presence of a high concentration of homologous transcripts. In situ hybridization to 5S RNA with a complementary strand probe resulted in the concentration of a large number of grains at 56EF (Karpen 1987), the location of the 5S genes (Pardue and Gall 1972; Artavanis-Tsakonis et al. 1977). Yet, in no case did the grains extend substantially beyond the confines of the chromosome, in contrast to observations on the autosomal rib,ry inserts.

Although the nucleolus is associated only with the NO region in intact polytene nuclei (Hochstrasser and Sedat 1987), nucleolar material can be observed at other sites in specially prepared salivary-gland squashes (Hill and Watt 1977; Ananiev et al. 1981). Therefore, a quantitive analysis of the data from the RNA in situ preparations was undertaken to determine whether the presence of mininucleoli at rib,ry insertion sites was due to random or nonrandom associations between fragments of the endogenous nucleolus and the chromosomes. Each nucleus was scored for the presence of mininu- 
Table 1. Results of in situ hybridization to rRNA

\begin{tabular}{|c|c|c|c|c|c|c|c|c|}
\hline \multirow[b]{2}{*}{ Site $^{a}$} & \multirow[b]{2}{*}{ Probe $^{b}$} & \multirow[b]{2}{*}{$S^{c}$} & \multirow[b]{2}{*}{$\mathrm{N}^{d}$} & \multicolumn{5}{|c|}{ Average number of grains ${ }^{\mathrm{e}}$} \\
\hline & & & & $2 B$ & $1 \mathrm{~A}$ & $23 E$ & $68 \mathrm{BC}$ & $94 \mathrm{~B}$ \\
\hline \multirow[t]{2}{*}{ 1A female } & ETS-C & 3 & 115 & $0.060(112)$ & $3.78 \quad(108)$ & $0.027(39)$ & $0.036(36)$ & $0.022(43)$ \\
\hline & ETS-NC & 2 & 73 & $0.022(73)$ & $0.110(73)$ & - & - & - \\
\hline \multirow[t]{2}{*}{ IA male } & ETS-C & 3 & 93 & $0.021\langle 81\rangle$ & $0.478(81)$ & $0.003(26)$ & $0.011(39)$ & $0.006(31)$ \\
\hline & ETS-NC & 1 & 18 & $0.005(18)$ & $0.019(18)$ & - & - & - \\
\hline $23 \mathrm{E}$ & ETS-C & 2 & 69 & $0.033(43)$ & $0 \quad\{42\}$ & $1.37(46)$ & $0.006(27)$ & $0.004(21)$ \\
\hline $23 \mathrm{E}$ & ETS-NC & 1 & 16 & $0 \quad(12)$ & - & $0.010(16)$ & - & - \\
\hline $68 \mathrm{BC}$ & ETS-C & 4 & 111 & $0.024(72)$ & $0.064\langle 73\rangle$ & $0.006(26)$ & $3.07(71)$ & $0.020(57)$ \\
\hline $94 \mathrm{~B}$ & ETS-C & 4 & 184 & $0.023(142)$ & $0.035(143)$ & $0.028(75)$ & $0.012(55)$ & $1.26(105)$ \\
\hline $94 \mathrm{~B}$ & ETS-NC & 2 & 29 & $0.021(16)$ & - & - & - & $0.009(29)$ \\
\hline
\end{tabular}

a Chromosome squashes prepared from the [rib7] line with a rib,ry insert at the site indicated. Preparations were from female larvae

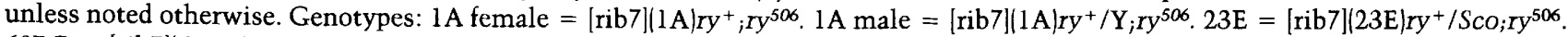
$68 \mathrm{BC}=[\mathrm{rib} 7] \mid 68 \mathrm{BC}) r y^{+} r y^{506} .94 \mathrm{~B}=[\mathrm{rib} 7](94 \mathrm{~B}) r y^{+} r y^{506}$.

b See Materials and methods for a description of the probes.

c Total number of slides scored.

d Total number of nuclei scored.

e Number of grains associated with the integration site per nucleus per day of exposure; the number of nuclei scored for each site is reported in parentheses.

cleoli at five sites, corresponding to the rib,ry insertion sites in the four lines (1A, 23E, 68BC, and 94B), and a randomly chosen site $(2 \mathrm{~B})$, which never contained a rib,ry insert. Sites were scored as positive for the presence of a mininucleolus when they were attached to a structure that extended beyond the confines of the chromosome and contained $>10$ autoradiographic grains. The autosomal rib,ry inserts were scored positive for the presence of a mininucleolus when the area of hybridization extended significantly beyond that observed for the 5S genes (approximately more than one-half the diameter of the chromosome; see above and Karpen 1987).

The analysis of the in situ hybridization to rRNA preparations demonstrated that mininucleoli were associated preferentially with the sites of rib,ry insertion in all four transformed lines (Table 2). Random associations between chromosome arms and fragments of the endogenous nucleolus were rare in these preparations, because site $2 \mathrm{~B}$ was never $(0 \%, n=480)$ associated with a mininucleolus in any of the lines tested. In the absence of inserts at $1 \mathrm{~A}, 23 \mathrm{E}, 68 \mathrm{BC}$, or 94B, nonrandom associations of these regions with fragments of the endogenous nucleolus also were infrequent. For example, site 1A displayed a mininucleolus in $33 \%$ of the nuclei analyzed from [rib7] $(1 \mathrm{~A})$ females, but in only $1.1 \%$ of the nuclei from lines [rib7] (23E), (68BC), and (94B) combined (Fig. $3 \mathrm{~b})$. The frequencies of mininucleolus association for the three other sites also were substantially higher in lines containing a rib,ry insert at that site, in comparison to lines in which it was absent (Fig. 3b). Because 14\% of the nuclei did not contain a visible endogenous nucleolus ( $n=561$ nuclei), it is likely that the method of chromosome preparation (squashing) disrupts some of the nu- cleolus-chromosome associations (Viinikka et al. 1971). Therefore, the frequencies of mininucleoli associated with the rib,ry integrants are probably underestimates of the true in vivo frequency.

The frequencies of mininucleolus association for three of the rib,ry lines [1A (in females), 23E, and 68BC] were similar to each other, but differed from the frequencies observed for 94B and 1A (in males) (Table 2, Fig. 3b). Lines 1A (in females) and 68BC displayed high frequencies of mininucleolus association $133 \%$ and $38 \%$, respectively). The heterozygosity of the $23 \mathrm{E}$ insert probably contributes to the low $(20 \%)$ frequency of association of this site with a mininucleolus; this value is within a factor of 2 of the $1 \mathrm{~A}$ and $68 \mathrm{BC}$ frequencies. The homozygous insert at 94B, however, was associated with a mininucleolus in only $16 \%$ of the nuclei; sequences flanking this insert may exert a position effect on rDNA functions, such as transcription or endoreplication. Similarly, the low frequency of mininucleoli observed at the rib,ry insertion site in $1 \mathrm{~A}$ males $(2.5 \%)$ is 6.6 -fold lower than the frequency in $1 \mathrm{~A}$ females, after correcting for the $2: 1$ (female:male) difference in dosage of the insert. This result parallels the reduced transcript levels of the rDNA insert in 1A males, relative to 1A females /nearly a fourfold reduction, as measured by in situ hybridization to rRNA, and after correcting for gene-dosage differences; see Table 1). The differential behavior of the $1 \mathrm{~A}$ rib,ry insert in males and females needs to be investigated further; one possible explanation is that the $\mathrm{Y}$ chromosome rRNA genes may be expressed or endoreplicated (Endow and Glover 1979) dominantly in male tissue, at the expense of the X-linked genes.

Mininucleolus size was assessed for each site by de- 

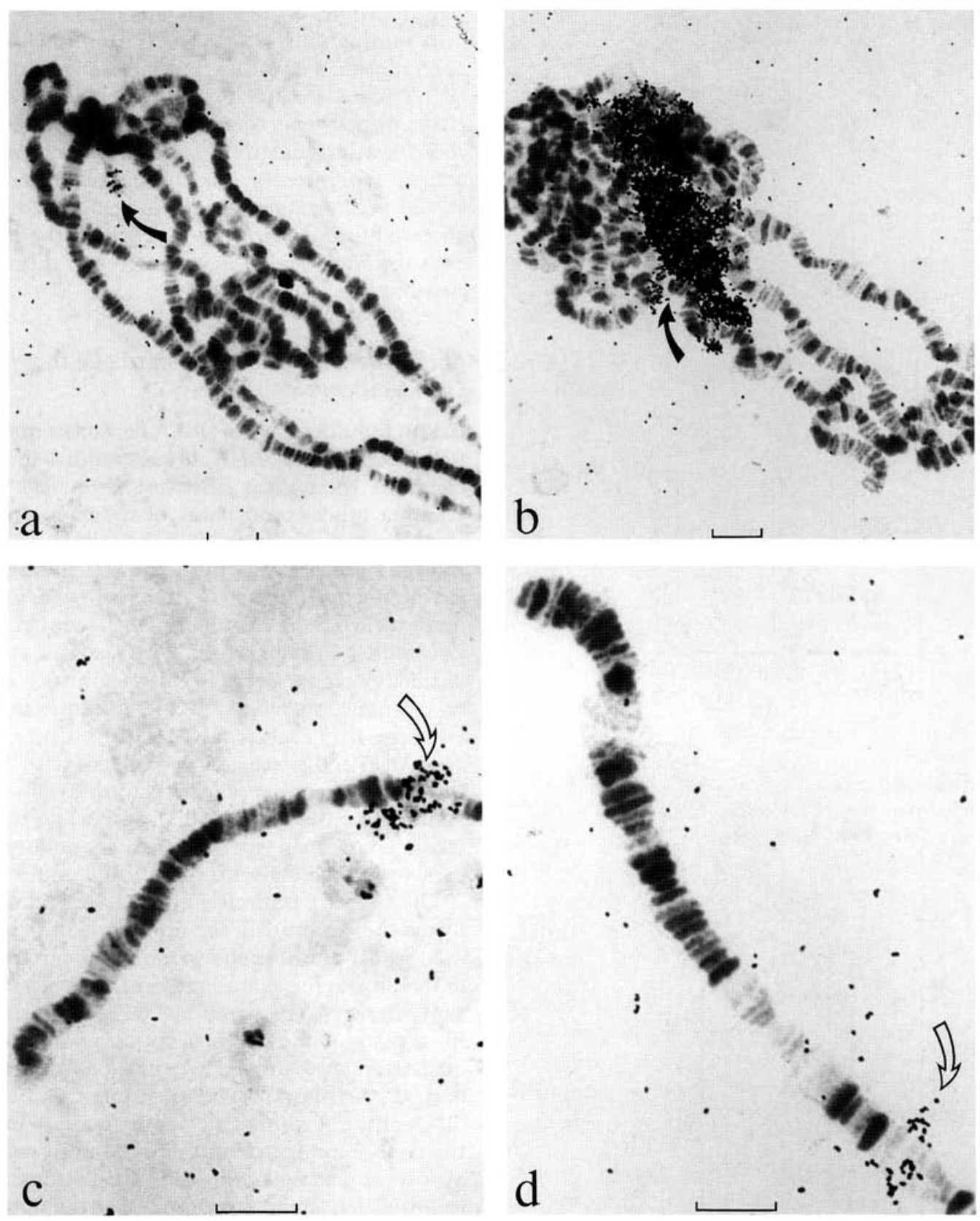

Figure 2. Comparison of polytene chromosomes after in situ hybridization with noncomplementary (ETS-NC) and complementary (ETS-C) strand probes. (a) Hybridization with ETS-NC probe; slide was exposed for 12 days. The few grains present are concentrated in the central portion of the nucleolus (solid arrow), in the fibrous region known to contain the rDNA (Pardue et al. 1970; Goessens 1984). (b) Hybridization with the ETS-C probe; slide was exposed for 11.5 days. Grains are much more abundant and dispersed throughout the nucleolus (solid arrow) in comparison to $a$. ( $c$ and $d$ ) Complementary strand probe hybridization to [rib7]|68BC) ry ${ }^{+}$ $r y^{506}$ and [rib7] (94B) $r y^{+} r^{506}$, respectively. Exposures for 11 days $(\mathrm{c})$ and 12 days $(d)$. Open arrows point to the sites of rib,ry insertion. Bar represents $10 \mu \mathrm{m}$.

termining (1) the average number of grains per mininucleolus, and (2) the size (area) relative to the endogenous nucleolus present in the same nucleus. Size varied somewhat among individual nuclei with the same insertion site (Fig. $4 a-c$ ), as well as among the four lines (Table 2). For example, mininucleoli at $23 \mathrm{E}$ ranged be- tween $4 \%$ and $50 \%$ of the size of the endogenous nucleolus, with an average of 6.5 grains per mininucleolus per day of exposure, whereas the insert at $1 \mathrm{~A}$ was associated with mininucleoli $2.5-100 \%$ the size of the endogenous nucleolus, with a 10-grain average per mininucleolus per day of exposure. The significance of these 
a)

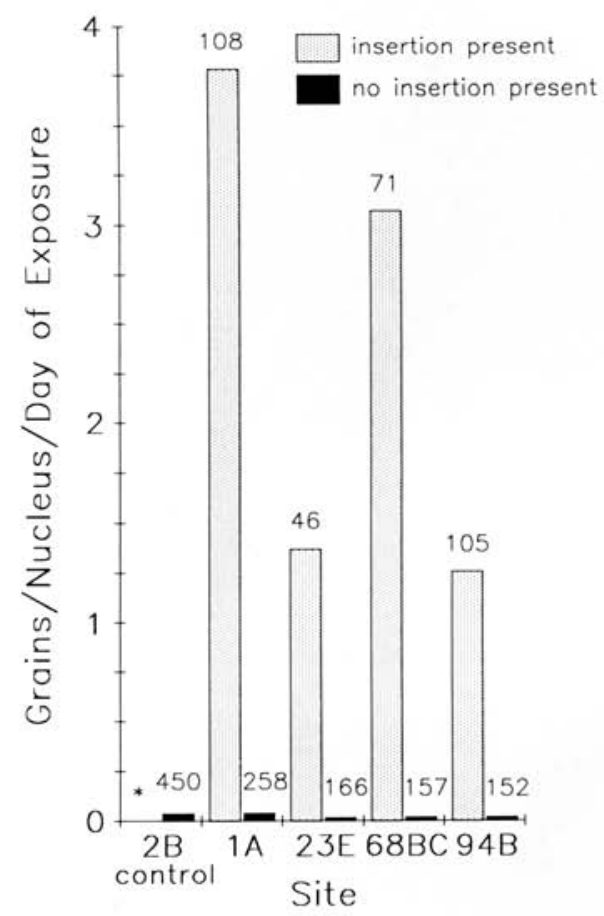

b)

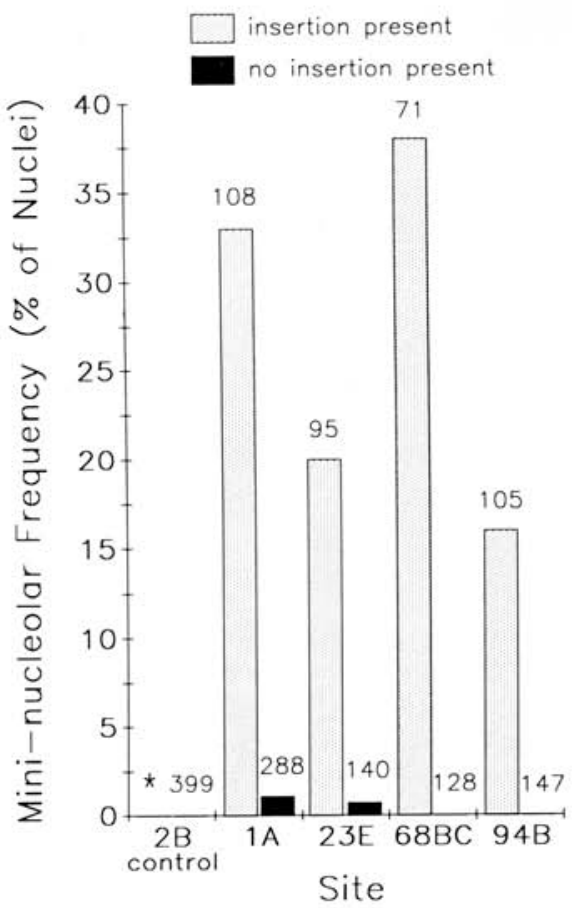

Figure 3. Summary of results of in situ hybridization to rRNA. (a) The grains/nucleus · day of exposure (Table 1) were summed for all nuclei with (stippled bar) or without (solid bar) a rib,ry insert, at the site indicated. $(b)$ The frequencies of association with the mininucleoli (Table 2) were summed for all nuclei, with and without a rib,ry insert at the site indicated. Numbers above the bars indicate the total number of nuclei. $\left({ }^{*}\right) 2 B$ included as a no-insert control. $1 \mathrm{~A}$ includes data from $1 \mathrm{~A}$ females only. size variations is unclear at this time.

In summary, in situ hybridization to rRNA has demonstrated that four different sites of insertion of single rRNA genes are preferentially associated with mininucleoli in polytene chromosomes. The presence of high concentrations of rRNA, and the extrachromosomal, attached structure of the mininucleoli are properties shared with the endogenous nucleolus. Variations were observed in the frequency and size of the mininucleoli; both technical and biological bases to this variation are possible.

\section{Mininucleoli stain with an antibody that binds to Drosophila nucleoli}

In situ hybridization to rRNA demonstrated that mininucleoli contained rRNA and resembled endogenous nucleoli in their gross structure. We have investigated whether other components of the endogenous nucleoli were present in mininucleoli by staining polytene chromosome preparations from the transformed lines with the monoclonal antibody Aj1 (Saumweber 1980), which binds to a 47,000-dalton nucleolar antigen present in Drosophila interphase nuclei (Frasch et al. 1986). This antibody reacted strongly and specifically with both the endogenous nucleoli and the mininucleoli associated with the rib,ry insert at $1 \mathrm{~A}$ (Fig. 5). Comparison of the Nomarski and phase-contrast images with the pattern of fluorescence demonstrated that all visible mininucleoli stained positively for the antigen. Therefore, mininucleoli contain an antigen that, in polytene nuclei, is present at high concentration only in nucleoli.

The indirect immunofluorescence technique also allowed the structure of the mininucleoli to be assessed in cytological preparations without the interference of the autoradiographic grains present after in situ hybridization to rRNA. Preparations were analyzed using Nomarski and phase-contrast optics, and the mininucleoli qualitatively resembled the endogenous nucleoli in both optical systems (phase-contrast images are shown in Fig. 5). Qualitative similarities, most notably in the color of the endogenous nucleolus and the mininucleoli (Fig. 6), also were observed after heat shock of salivary glands, followed by Giemsa staining of the polytene chromosome squashes (see Materials and methods; Karpen 1987).

Phenotypic rescue of bobbed mutations by a transformed $r$ RNA gene

A genetic approach was undertaken to determine whether the rib,ry inserts and their associated mininucleoli were able to produce functional rRNA that provides the cell with ribosomes active in protein synthesis. Rib,ry inserts were tested for their ability to rescue three phenotypes associated with rDNA deficiencies (bobbed mutations, $b b$ ): etched abdominal cuticle, lethality, and delayed development/eclosion ( $\mathrm{Ri}$ tossa 1976). Reduced levels of rRNA and protein synthesis in response to an rDNA deficiency are believed to 

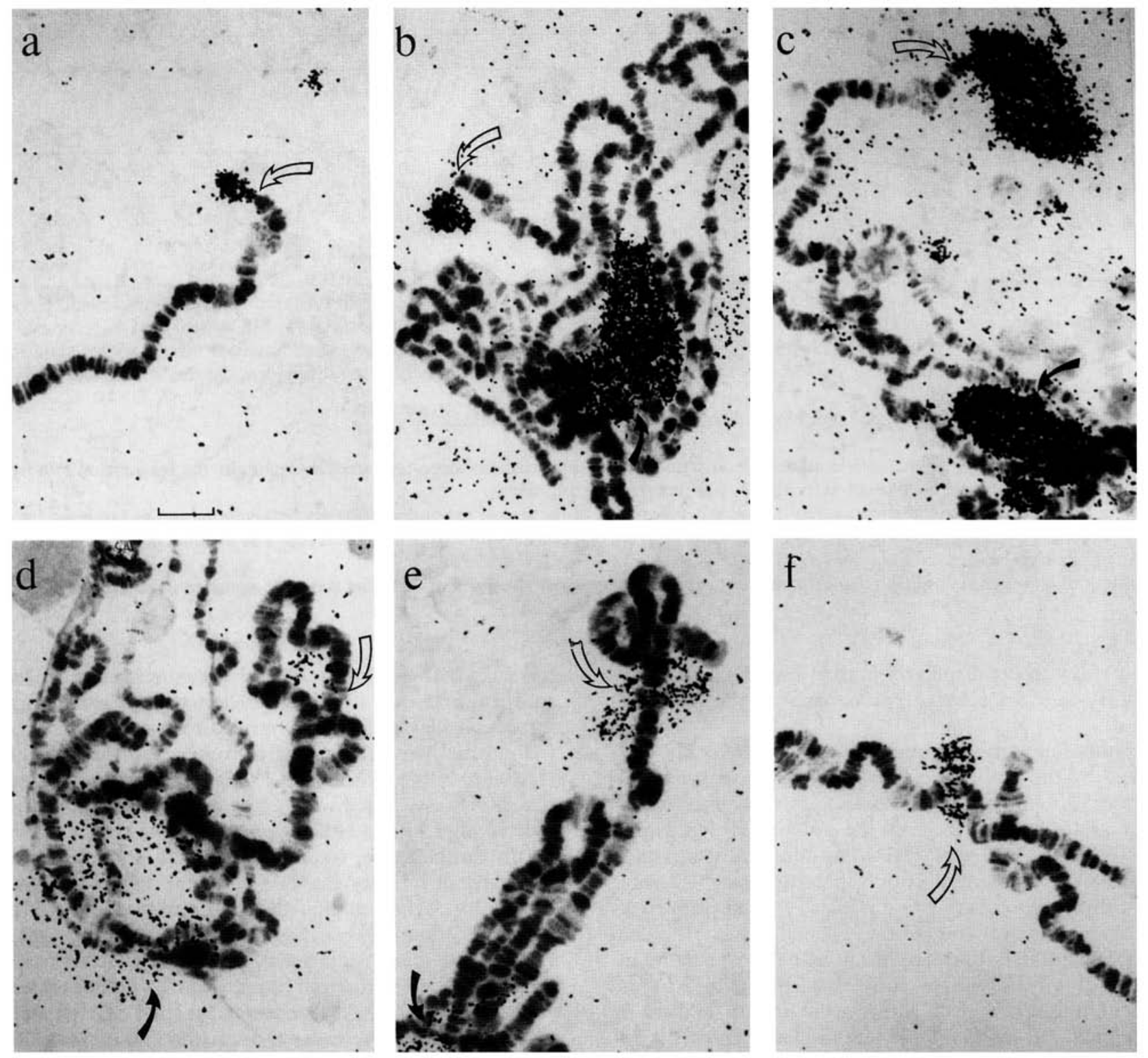

Figure 4. Mininucleoli visualized at four rib,ry insertion sites by in situ hybridization to rRNA. $(a-c)\left[\right.$ rib7] $(1 \mathrm{~A}) \mathrm{ry}^{+}$; ry $\mathrm{r}^{506}(11.5$-day exposure; all from the same female). (d) [rib7] (23E) $\mathrm{ry}^{+} / \mathrm{Sco} \mathrm{ry}^{506}$ (12-day exposure). (e) [rib7](68BC) ry ${ }^{+} \mathrm{ry}^{506}$ (11.5-day exposure). ( $f$ ) [rib7] (94B) $r y^{+} r y^{506}$ (12-day exposure). Open arrows point to the sites of rib,ry insertion; solid arrows indicate the endogenous nucleolus. Bar represents $10 \mu \mathrm{m}$.

be the causes of the bobbed phenotypes (Ritossa 1976; DeSalle and Templeton 1986).

The viability of genotypically bobbed animals improved greatly in the presence of a rib,ry insert. Cumulative eclosion was measured for four genotypes $\left(b b^{+} / b b\right.$; $b b / b b$ with no insert, with a heterozygous rib,ry insert, and with a homozygous rib,ry insert) on each day of culture, up to 22 days after egg laying. There was a 3.2 -fold increase in the total number of eclosed adults homozygous for a rib,ry insert at site $1 \mathrm{~A}$ in comparison to the no-insert control (day 22, Fig. 7a). In addition, more homozygotes eclosed earlier than the no-insert controls throughout most of the culture period, and the time at which $50 \%$ of the total adult homozygotes eclosed (the median time of eclosion) was $>1$ day earlier than the median time of eclosion for the no-insert controls (18.7 versus 20 days). The homozygous insert at $1 \mathrm{~A}$ did not completely rescue the $b b$ lethality, because total eclosion was $75 \%$ of the value for the $b b^{+}$control (versus $24 \%$ when the no-insert control was present) and the eclosion time for animals with a homozygous rib,ry insert (median time of eclosion $=18.7$ days) was still increased in comparison to the $b b^{+}$controls /median time of eclosion $=15.2$ days). Animals heterozygous for the 
Table 2. Analysis of mininucleoli visualized by in situ hybridization to $r$ RNA

\begin{tabular}{|c|c|c|c|c|c|c|c|c|c|c|}
\hline \multirow[b]{3}{*}{ Line $^{\mathbf{a}}$} & \multirow[b]{3}{*}{$S^{b}$} & \multirow[b]{3}{*}{$\mathrm{N}^{\mathrm{c}}$} & \multicolumn{8}{|c|}{ Mininucleoli } \\
\hline & & & \multicolumn{5}{|c|}{ frequency at sites ${ }^{d}$} & \multicolumn{2}{|c|}{ size $^{e}$} & \multirow[b]{2}{*}{ Grains $^{f}$} \\
\hline & & & $2 B$ & $1 \mathrm{~A}$ & $23 \mathrm{E}$ & $68 \mathrm{BC}$ & $94 \mathrm{~B}$ & mean & range & \\
\hline 1A female & 3 & 115 & $0(112)$ & $33\{108\}$ & $0 \quad|39|$ & $0(36)$ & $0(43)$ & $11|32|$ & $2.5-100$ & $10 \quad(36)$ \\
\hline $1 \mathrm{~A}$ male & 3 & 93 & $0(81)$ & $2.5(81)$ & $0 \quad(26)$ & $0(39)$ & $0(31)$ & - & - & - \\
\hline $23 \mathrm{E}$ & 5 & 126 & $0(73)$ & $0 \quad(72)$ & 20 & $0(37)$ & $0(47)$ & $11(12)$ & $4-50$ & $6.5(19)$ \\
\hline $68 \mathrm{BC}$ & 4 & 111 & $0(72)$ & $1.4(73)$ & $0 \quad(26)$ & $38(71)$ & $0(57)$ & $24(20)$ & $8.3-75$ & $6.8(27)$ \\
\hline $94 \mathrm{~B}$ & 4 & 184 & $0(142)$ & $0.7(143)$ & $1.3(75)$ & $0(55)$ & $16(105)$ & $47(3)$ & $7.7-100$ & $5.8(17)$ \\
\hline
\end{tabular}

a Chromosome squashes prepared from the [rib7] line with a rib,ry insert at the site indicated. Preparations were from female larvae

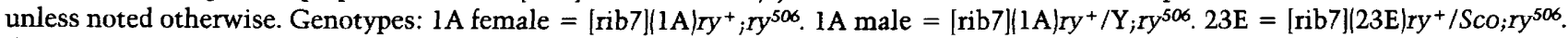
$68 \mathrm{BC}=[\mathrm{rib} 7](68 \mathrm{BC}) r y^{+} r y^{506} .94 \mathrm{~B}=[\mathrm{rib} 7](94 \mathrm{~B}) r y^{+} r y^{506}$. All results from hybridization with complementary strand probes $(\mathrm{data}$ for $1 \mathrm{~A}, 68 \mathrm{BC}$, and $94 \mathrm{~B}$ involved the probe ETS-C exclusively, whereas the data for 23E include the results from probes ETS-C and 130-C; see Materials and methods).

b Total number of slides scored; one pair of glands from one animal on each slide.

c Total number of nuclei scored.

d Percentage of nuclei with mininucleoli associated with the site indicated (boldface type used to highlight the integration-site frequencies); the number of nuclei scored for that site is reported in parenthesis.

e Size (area) of mininucleoli at the integration site, as a percentage of the size of the endogenous nucleolus found in the same nucleus. Relative areas were estimated with an ocular grid while viewing preparations through the microscope. The number of nuclei scored is reported in parenthesis.

${ }^{\mathrm{f}}$ Number of grains in the mininucleoli per nucleus per day of exposure; the number of nuclei scored is reported in parenthesis.

same rib,ry insert displayed similar, but slightly lower, viability and eclosion in comparison to the homozygotes.

Abdominal cuticle formation also was visibly improved by the presence of the rib,ry insert in genotypically $b b / b b$ adults. Progeny were classified into one of three groups on the basis of the amount of adult, pigmented abdominal cuticle: from no adult cuticle to onethird of the abdominal cuticle present (class 1); from one-third to two-thirds present (class 2); and from twothirds present to completely normal (class 3 ). The highest fraction of the eclosed adults $(63 \%)$ was found in class 1 (least amount of cuticle) when no insert was present (Fig. 7b); fewer adults were found in class 2 $(22 \%)$ and still fewer $(15 \%)$ were in class 3 (nearly wild type). In contrast, the largest class of animals with a homozygous rib,ry insert was found in class $3(42 \%)$, whereas only $28 \%$ was in class 1 . Rescue of abdominal etching appeared to be more sensitive to dosage of the rib,ry insert than rescue of lethality; the values for heterozygotes were between those observed for the homozygotes and the no-insert controls (Fig. 7b).

In summary, the lethality, delay in time of eclosion, and abdominal etching phenotypes associated with the bobbed mutations were reduced in the presence of the rib,ry insert at $1 \mathrm{~A}$. Therefore, we conclude that the rib,ry inserts can complement an rDNA deficiency; this suggests that the rRNA observed at the sites of rib,ry integration is functional, providing the mature rRNA necessary for ribosome assembly and protein synthesis.

\section{Discussion}

We have inserted a single rRNA gene into a variety of euchromatic locations, using P-element-mediated trans- formation. To our knowledge, these experiments constitute the first case in which P-element-mediated transformation was used to insert into euchromatin a gene that normally resides in heterochromatin. In situ hybridization to rRNA, a technique that localized and quantified rRNA associated with ectopic integration sites, indicated that single rRNA genes inserted into euchromatin can be active transcriptionally in polytene chromosomes of salivary glands. Of special importance was the ability of the ectopic rRNA genes to rescue partially the three mutant phenotypes associated with rDNA deficiencies (bobbed mutations), which demonstrated that the rib,ry inserts produced functional rRNA. The formal possibility that the rRNA observed at the insertion sites was transcribed elsewhere (i.e., in the endogenous nucleolus) and transported to the insertion sites is unlikely given the results of the bobbed rescue experiments. The observation that transcripts (grains) tend to be clustered near the chromosomal side of the mininucleoli after a short pulse of $\left[{ }^{3} \mathrm{H}\right]$ uridine incorporation during heat shock (see Fig. 6; also Karpen 1987) strengthens the view that rRNA is made at the ectopic sites.

In situ hybridization to rRNA also indicated that a structure resembling, but physically separate from, the endogenous nucleolus was associated preferentially with four different euchromatic sites of rib,ry insertion; these same four sites were not associated with a mininucleolus when a rib,ry insert was not present. Gross qualitative similarities between the endogenous and mininucleoli also were observed in a variety of cytological analyses, including Nomarski and phase-contrast optics, and Giemsa staining after heat shock. The results of the in situ hybridization to rRNA and indirect immunofluorescence analyses demonstrated that mininucleoli (as well as the endogenous nucleoli) contained 

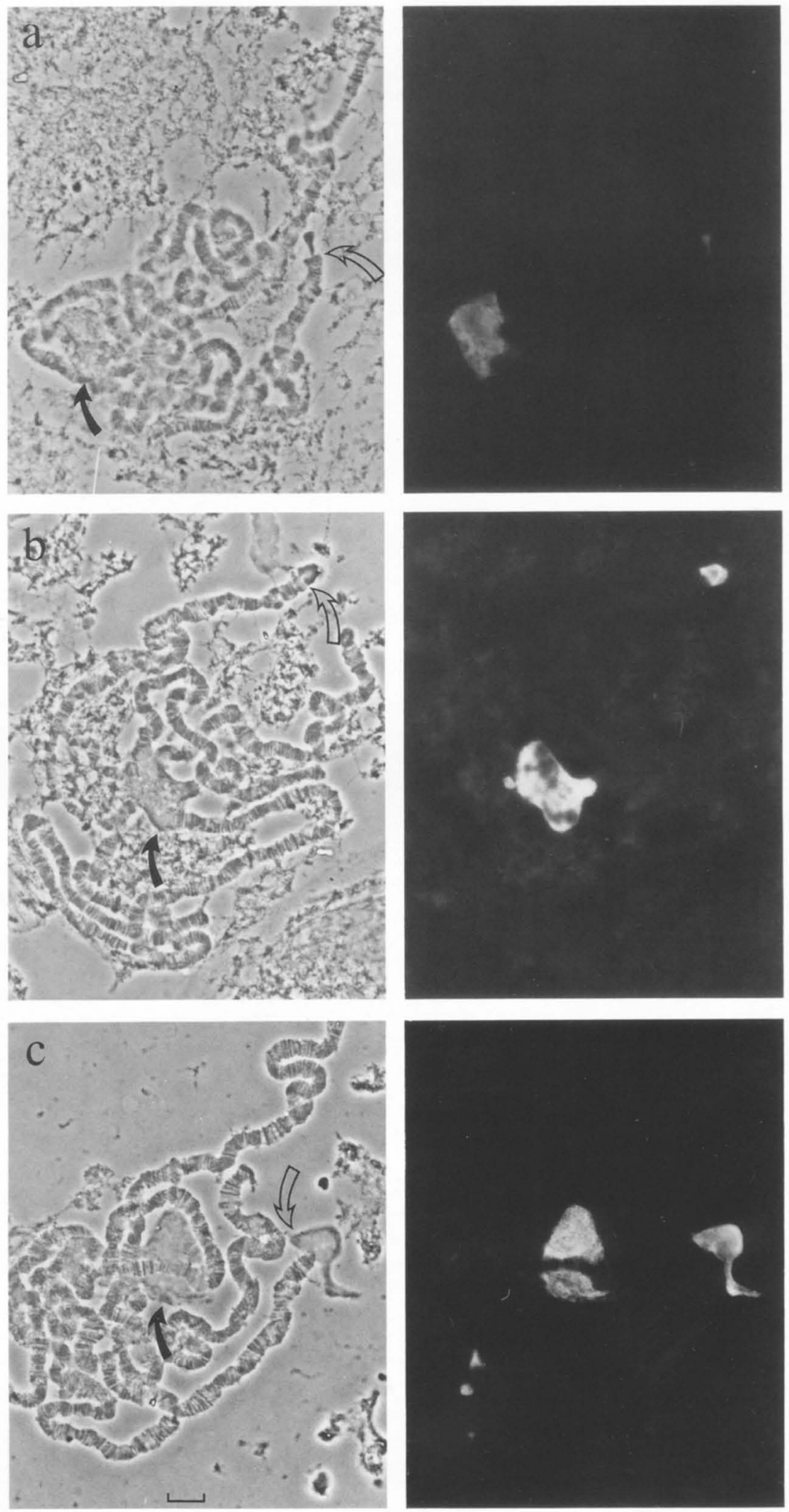

Figure 5. Binding of an antinucleolar antibody to mininucleoli. Examples of three nuclei from [rib7](1A) females, after staining with the Ajl antibody. (Left) Phase-contrast images; (right) fluorescence images of the same nuclei. Open arrows point to $1 \mathrm{~A}$, the site of rib,ry insertion. Solid arrows indicate the endogenous nucleolus. Bar represents $10 \mu \mathrm{m}$. Variations in the thickness of parts of these preparations makes it difficult to bring all elements into focus. Note that the textures of the mini- and endogenous nucleoli appear similar when both are in the same focal plane (i.e., as in $c$ ). 


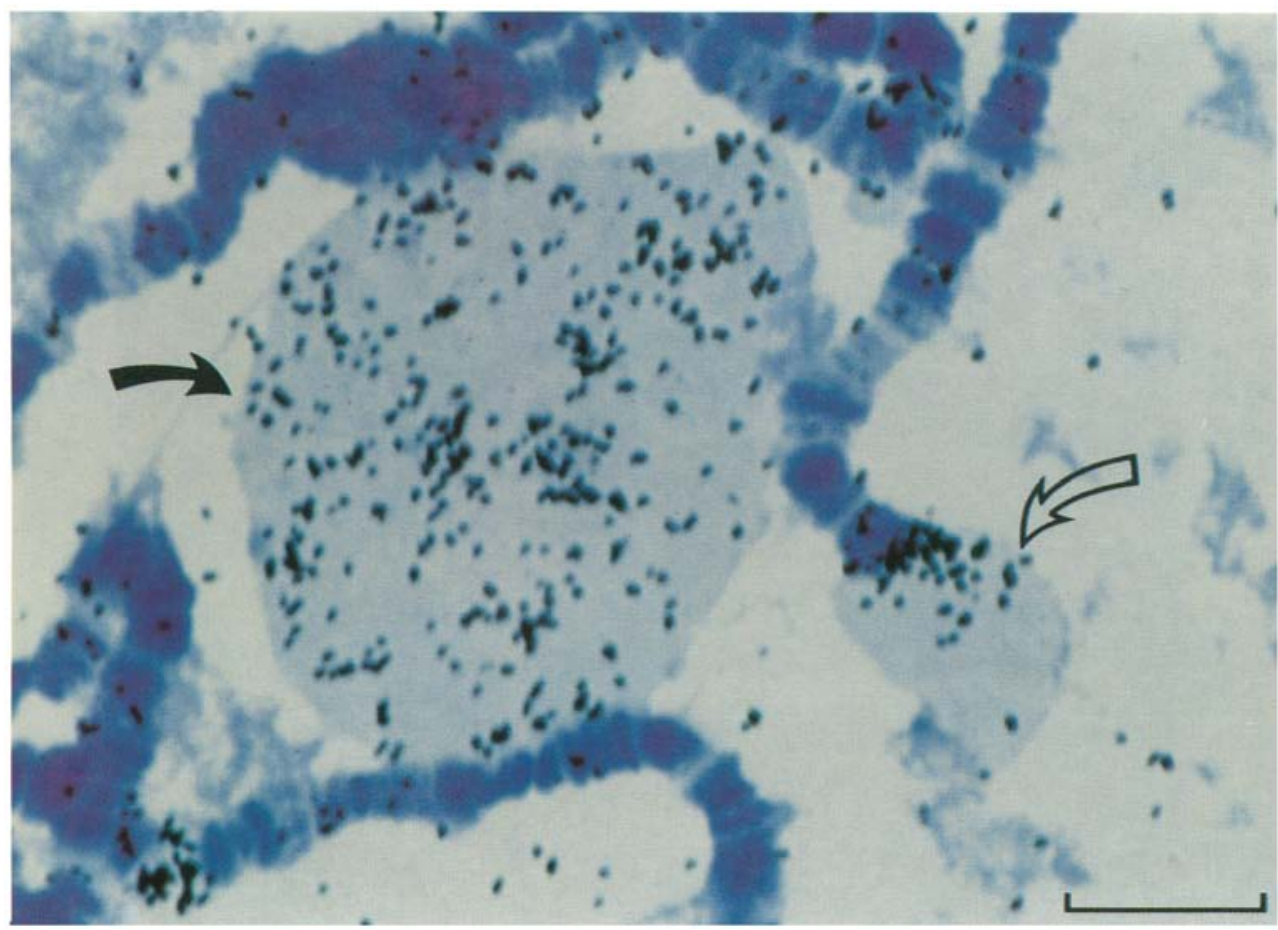

Figure 6. Giemsa staining of the mininucleolus and endogenous nucleolus after heat shock and $\left[{ }^{3} \mathrm{H}\right]$ uridine incorporation. Nucleus from [rib7] $(1 \mathrm{~A}) \mathrm{ry}^{+} ; r y^{506}$ females, pulse-labeled and prepared as described in Materials and methods. Open arrow points to the mininucleolus at the tip of the $X$ chromosome $(1 \mathrm{~A})$; solid arrow indicates the endogenous nucleolus. Note that the color and texture of the mininucleolus and endogenous nucleolus are identical, but differ from the chromosomes, puffs, and other nuclear components. Bar represents $10 \mu \mathrm{m}$.

rRNA and a nucleolar antigen; in the absence of the ectopic rRNA genes, both components are concentrated in only one part of the interphase nucleus, the endogenous nucleolus. Finally, our observation that rib,ry integrants partially rescued three bobbed mutant phenotypes resulting from partial deletion of the endogenous rDNA demonstrates that the mininucleoli associated with sites of rDNA insertion can function as nucleoli. Therefore, we conclude that a single, polytenized rRNA gene can form a nucleolus when located in euchromatin. These results bear on our understanding of the relationship between the unusual organization of the NO and the ability of rDNA to function.

\section{rDNA function and tandem repetition}

rRNA genes are repeated tandemly in most of the eukaryotic organisms studied to date (Long and Dawid 1980). This extraordinary conservation of organization across wide evolutionary distances could result from a common functional requirement for tandem repetition. The ability of cloned rDNA fragments to be transcribed in a variety of in vivo and in vitro assays (for review, see Sollner-Webb and Tower 1986; also see Dhar et al. 1985; Elion and Warner 1986; Grimaldi and Di Nocera 1986; Vance et al. 1985/ demonstrates that tandem repetition is not an absolute requirement for rRNA gene expres- sion. However, recent analyses in Drosophila (Tautz and Dover 1986) and Xenopus (Labhart and Reeder 1986) have demonstrated that polymerase I transcription can continue beyond the 3 ' end of the $28 \mathrm{~S}$ rRNA sequences, to the $5^{\prime}$ regulatory region of the downstream gene. In vitro and in vivo analyses indicate that termination sites associated with the promoter also can act to increase transcriptional activity (Grummt et al. 1986; Henderson and Sollner-Webb 1986; McStay and Reeder 1986). These observations suggest that tandem repetition of rRNA genes may play a role in optimizing rDNA transcription (Baker and Platt 1986; Reeder et al. 1987) and thus could contribute to the regulation of rDNA function in cells subject to environmental and developmental stresses.

The transcriptional activity of the single genes present in the rib,ry integrants clearly indicates that tandem repetition is not an absolute requirement for this aspect of in vivo $\mathrm{rDNA}$ function in $D$. melanogaster. Moreover, it is likely that tandem repetition is not necessary for high levels of rDNA expression. In many nuclei, the relative activities of the transformed and endogenous rRNA genes appear similar, when the number of grains observed at the endogenous and ectopic sites in the transcription analysis are normalized for differences in gene copy number. From in situ hybridization to DNA in polytene chromosomes we determined that a homozygous insert contained $11.6 \%$ of the amount of $\mathrm{rDNA}$ in the 
nucleolus (Karpen 1987). This value appears to be high, because in a diploid nucleus there are only two copies of the transformed rRNA gene, which is $\sim 0.4-0.8 \%$ of the number of genes in the NOs. The exact number of rRNA genes in the Canton-S strain used in our studies is not known, but in other strains of $D$. melanogaster NOs contain 120-240 rRNA genes; Long and Dawid 1980.) However, rDNA in the NO is underreplicated in polytene nuclei, in comparison to its relative representation in diploid cells (Spear and Gall 1973; Endow and Glover 1979; Endow 1980; Hilliker and Appels 1982; Hammond and Laird 1985). If the rib,ry inserts were to replicate fully with the surrounding euchromatin, then their rep-

a)

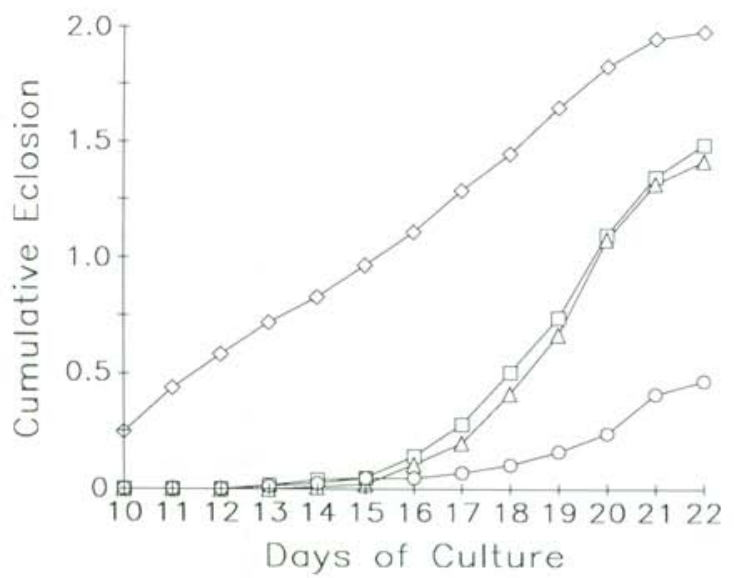

b)

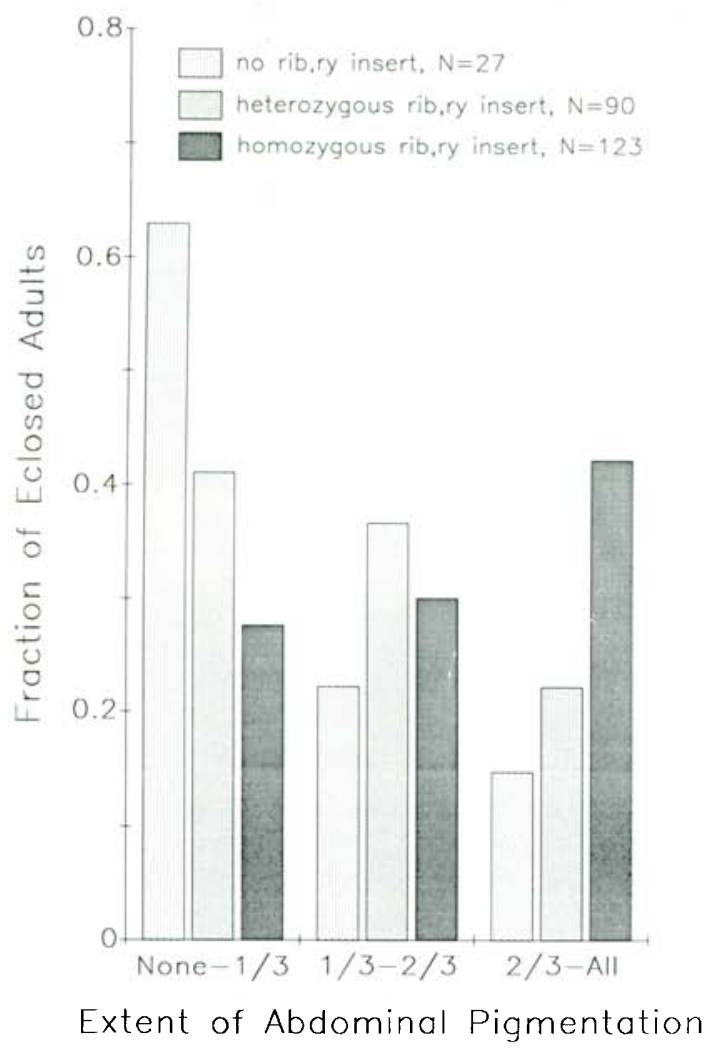

resentation relative to the endogenous rDNA would be increased. In situ hybridization to DNA demonstrated that the rosy sequences present in the rib,ry inserts replicated to the same extent as those at $87 \mathrm{D}$ (Karpen 1987). It is therefore likely that the rRNA genes in the inserts replicated to a level similar to the surrounding euchromatin. Assuming full replication of the inserted rDNA and that an average of 180 rRNA genes in each haploid NO (see above) are underreplicated 9.1-fold in late third-instar salivary glands (based on actual measurements for Canton-S; Hammond and Laird 1985), we estimate the relative contribution of the insertion site rDNA to be $\sim 5.7 \%$ in polytene nuclei. The values we measured after in situ hybridization to rDNA (11.6\%) are within a factor of 2 of this estimate. The ratio of grains at the insertion site to grains at the nucleolus was comparable to or greater than the $11.6 \%$ ratio of insert/ endogenous rDNA in $38 \%$ of the [rib7] $(68 \mathrm{BC})$ nuclei analyzed with in situ hybridizations to rRNA (Karpen 1987). The fraction of nuclei in which expression from the transformed rDNA is equal to or greater than the levels exhibited by genes in the endogenous NO would be even higher if the relative amount of template in the insertion site is actually closer to the $5.7 \%$ estimate derived above. Therefore, we conclude that tandem repetition of rRNA genes is not an absolute requirement for high levels of transcription in vivo.

In this study, transcriptional activity was directly monitored only in polytene nuclei, in which the ectopic rRNA genes are most likely laterally repeated. Thus, it is possible that high copy number facilitates expression, e.g., by increasing the local concentration of regulatory molecules, components of the transcriptional machinery or nucleotide precursors, and that either lateral or tandem repetition will suffice. However, linear access to adjacent ribosomal transcription units by RNA poly-

Figure 7. Rescue of bobbed phenotypes by a rib,ry insert. $(a)$ Lethality and delayed eclosion. The cumulative number of adult females (normalized to the total number of $F M 6 / Y$; ry ${ }^{506}$ males eclosed from the same viall on the indicated days of culture was plotted for the four different genotypes. Pharate adults whose heads emerged from the pupa case were scored as eclosed adults; the proportion of pharate pupae, relative to the total number of eclosed adults, was equivalent for all genotypes. Genotypes were as follows: (1) No rib,ry insert (0) $b b^{\text {r116/y mei-41 }}$ $b b^{s e v} ;[6 \Delta \mathrm{HS}] r y^{+} / r y^{506}$. (2) Heterozygous rib,ry insert $(\Delta)$

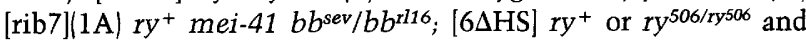

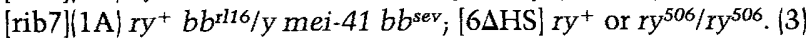
Homozygous rib,ry insert $(\square)[\mathrm{rib} 7](1 \mathrm{~A}) r \mathrm{ry}^{+} b b^{\text {r16 }} /[\mathrm{rib} 7](\mathrm{lA}) r y^{+}$ mei-41 bb $b^{s e v} ; y^{506}$. (4) bobbed ${ }^{+}(\diamond)-F M 6 / b b$ females (see Materials and methods). Total number of control FM6/Y; ry ${ }^{506}$ males were no rib,ry insert (87), heterozygous rib,ry insert (106), homozygous rib,ry insert (128), and bobbed ${ }^{+}(321)$. The total number of vials analyzed were $5,6,6$, and 17 , respectively. $(b)$ Abdominal etching. The fraction of total adult females falling into each abdominal pigmentation class is displayed for three different genotypes. $(N)$ Total number of adult females scored for abdominal pigmentation. Genotypes and number of vials are described for $a$. 
merase I, a possible explanation for the high density of transcripts observed on tandemly repeated rRNA genes (for review, see Baker and Platt 1986; Reeder et al. 1987), would not be applicable to laterally-repeated rRNA genes.

Why is a single rDNA insert partially able to rescue bobbed phenotypes resulting from significant deletion of endogenous rDNA? The rDNA content in the heteroallelic combination of bobbed alleles used in this study $\left(b b^{\text {sev }} / b b^{\text {r116 }}\right)$ appears to be close to the minimum number required for viability, because most mutant animals die as pharate adults, and the few animals that do eclose display extreme abdominal etching (Fig. 7). The addition of one or two rRNA genes may allow diploid cells partially to overcome this deficiency of endogenous rDNA. Alternatively, the ability of an rDNA insert to rescue bobbed phenotypes may reflect the dependence of Drosophila development and viability on the function of endoreplicated (polytenized) cells and tissues. The importance of rDNA function in endoreplicated cell types to the adult phenotype is supported by studies of a bobbed-like mutant (abnormal abdomen) in Drosophila mercatorum. The abdominal etching phenotype of $a b$ normal abdomen mutants appears to be caused by a reduction in the levels of a protein (juvenile hormone esterase) produced by a polytenized tissue, the fat body (Templeton and Rankin 1978; DeSalle and Templeton 1986). We discussed previously how underreplication of the rDNA in the endogenous NO allows a single, fully replicated rDNA integrant to constitute a significant fraction (between $5.7 \%$ and $11.6 \%$ ) of a polytene cell's rDNA. The functional contribution of the ectopic rDNA is likely to be higher than the relative DNA level, because insert-containing genes in the endogenous NO are not normally transcribed (Long and Dawid 1979; Jamrich and Miller 1984; Dawid and Rebbert 1986).

\section{rDNA function and chromosomal location}

The chromosomal position of NOs in eukaryotes is also conserved in the sense that in almost all species studied to date, NOs are located in constitutive heterochromatin and/or centromeric or telomeric regions /see references in Lima-de-Faria 1976, 1983; Long and Dawid 1980; Karpen 1987). Heterochromatic regions are thought to contain fewer genes and generally are less transcriptionally active than euchromatin (Muller and Painter 1932; Cooper 1959; Ananiev and Gvozdev 1974; Frenster 1974; Lakhotia and Jacob 1974; Hilliker et al. 1980). Classical genetic analyses have indicated that there may be a functional basis to the conservation of NO location. In D. melanogaster, the two NOs are located in the centromeric heterochromatin of the $\mathrm{X}$ and $\mathrm{Y}$ chromosomes (Ritossa and Spiegelman 1965). Chromosome rearrangements that juxtapose large blocks of euchromatin and centromeric heterochromatin, some involving the NO (Hannah-Alava, 1971; J. Spofford and R. DeSalle, in prep.), can result in inactivation or variegation of nearby euchromatic genes. Similarly, inversions and transpositions that move the NO into euchro- matin appear to result in the variegation of nucleolus formation (Baker 1971; Hannah-Alava 1971; Hilliker and Appels 1982) and decreased rDNA transcription (Nix 1973). These results suggest that the NO may be located preferentially in heterochromatin to promote rDNA function and/or to protect euchromatic genes from rDNA-induced position effects. However, a lack of knowledge of the exact structure of the rearrangements and the composition of the NO leaves open the possibility that sequences other than the rDNA are directly responsible for the two types of NO-related position effects.

P-element transformation has provided a means to assess directly the importance of chromosome location to various rDNA functions. The experiments reported in this paper indicate that single genes located at all four different euchromatic sites examined are transcriptionally active in polytene nuclei, are associated with mininucleoli, and are able to complement bobbed mutant phenotypes resulting from deletion of most of the endogenous rRNA genes. Therefore, we conclude that heterochromatic location of the NO is not an absolute requirement for the synthesis and function of rRNA in $D$. melanogaster. If other heterochromatic genes (for review, see Hilliker 1980) function normally when inserted into euchromatin via P-element-mediated transformation, as we observed for rDNA, then the general role of heterochromatic location will need to be reassessed.

Is there a functional basis to the conserved location and organization of NOs? It is unknown whether ectopically located single rRNA genes would function competitively under the selection and stress of feral conditions, in comparison to their counterparts in the NO. Furthermore, functions that have not been analyzed in this study, such as rDNA replication (Szostak and Wu 1980; Larsen et al. 1986) or recombination mechanisms necessary for maintaining homogeneity among repeats or gene copy number (Dover 1982; Maeda and Smithies 1986), may be dependent on heterochromatic location of the NO and/or tandem repetition of rDNA. The behavior of the ectopic rRNA genes with respect to these parameters needs to be investigated. An alternative hypothesis, that the conserved location and organization of NOs is related to negative effects of rDNA on euchromatic genes, is discussed elsewhere (Karpen 1987; G.H. Karpen and C.D. Laird, in prep.).

\section{rDNA and the NO}

Elegant cytogenetic experiments, carried out over the last 50 years, have been directed toward identifying the underlying mechanisms responsible for nucleolus-organizing activity. Nucleolus formation can be inhibited when sequences adjacent to the NO are disrupted by chromosomal rearrangement (Durica and Krider 1978; Hilliker and Appels 1982) or laser microirradiation (Berns and Cheng 1971; Berns 1973). These results suggest that sequences extrinsic to the NO may act in cis to 'organize' a nucleolus around the rDNA. Other experiments support the view that nucleolar-organizing ac- 
tivity may be intrinsic to the rDNA. The NO of Zea mays can be separated, by chromosome rearrangements, into at least three different pieces, each capable of supporting nucleolus formation (McClintock 1934; Givens and Phillips 1976). Portions of the Drosophila NO, when translocated into various euchromatic sites, are also able to form a nucleolus (Baker 1971; Hannah-Alava 1971; Hilliker and Appels 1982). These data suggest that the organizers are repeated within the NO.

A molecular interpretation of these cytogenetic studies is hampered, in large part, because structural analyses of the NO and its surroundings are incomplete. For example, because the exact physical relationship between the rRNA genes and the NO is unclear in most organisms, the proposed extrinsic 'control' sequences may, in fact, be rRNA genes. Similarly, although NOs tend to be localized to centromeric, telomeric, and/or heterochromatic regions of the genome, the amount, distribution, properties, and functions of non-rDNA sequences, in and around the NOs, have not been well characterized |Givens and Phillips 1976; Hilliker and Appels 1982). Thus, from the cytogenetic experiments, it is unclear whether the sequences supporting nucleolus formation by NO fragments were rDNA.

Amphibian oocytes contain highly amplified, tandemly repeated extrachromosomal rRNA genes that are associated with micronucleoli (Miller and Beatty 1969). This observation suggests that rDNA plays a central role in nucleolus formation but does not address the role of tandem repetition. Furthermore, the behavior of rRNA genes in this specialized system may not be relevant to chromosomally located genes in somatic cells. In Xenopus, the extrachromosomal oocyte rRNA genes do differ significantly from the somatic chromosomal genes in their 5-methyldeoxycytosine content (Dawid et al. 1970). In addition, the amplification mechanism could include the transfer of organizing capability to the repeated rRNA genes from sequences within or near the NO.

Molecular studies investigating the ability of defined sequences to form a nucleolus can circumvent many of the difficulties associated with the cytogenetic approaches to this problem. A role for rDNA in the organization of the nucleolus in somatic cells was suggested by experiments in which the $5^{\prime}$ portion of a mouse rRNA gene, which lacked most of the $18 \mathrm{~S}$ and $28 \mathrm{~S}$ transcription units, was transformed into Chinese hamster cell lines (Dhar et al. 1985). Cotransformation with a dihydrofolate reductase $(d h f r)$ gene and amplification via stepwise selection for methotrexate resistance resulted in integration of the rDNA and dhfr sequences as long, amplified regions (presumably tandemly repeated). The ability of rDNA to act as a NO was suggested by the silver staining of portions of the amplified regions in a small percentage of the cells. However, this type of analysis only indicates that some nucleolar components were present; silver apparently stains proteins that are associated closely with the DNA (Babu and Verma 1985). Direct observations of cytologically visible nucleoli at the amplified regions and the ability of the in- serts to provide nucleolar functions would be difficult to investigate in this system and were not reported by Dhar et al. (1985). In addition, the structures of the large amplified regions in these cell lines are unknown; they may, e.g., contain non-rDNA sequences and/or heterochromatin, comparable to those surrounding the endogenous NO. Thus, the relative roles played by rDNA, tandem repetition, and surrounding NO sequences in rDNA transcription and nucleolus formation could not be assessed by this experiment.

The experiments reported here have circumvented some of the difficulties associated with interpreting previous analyses of the NO and extend the observations reported for the mouse rDNA fragment (Dhar et al. 1985). Unlike experiments involving chromosome rearrangements, germ-line transformation has allowed the behavior of defined sequences to be monitored when separated from the endogenous NO. Chromosomal integrants mimic the state of the rDNA in the somatic cells of most species more closely, in comparison to analyses using extrachromosomal DNA. Finally, the polytene chromosomes of Drosophila allowed direct visualization of nucleolar material, and genetic manipulations available in Drosophila made a test for nucleolar function possible. The ability of a single rRNA gene to form a mininucleolus in polytene nuclei indicates that in somatic cells, chromosomally located rDNA is capable of forming a nucleolus independent of the structure (tandem repetition of $\mathrm{rDNA}$ ), composition (presence of non-rDNA sequences), and location (heterochromatin) of the NO. These results confirm a key role for rDNA in nucleolus formation, which was inferred from the cytogenetic studies (McClintock 1934; Hannah-Alavah 1971; Givens and Phillips 1976; Hilliker and Appels 1982). We conclude that the nucleolar organizing activity of secondary constrictions is an intrinsic property of the rDNA or its RNA products. Thus, the relationship between rDNA and nucleoli may be analogous to other nuclear structures that are associated with highly active transcription units, such as puffs (Ritossa 1964; Simon et al. 1985a,b) and lampbrush loops in oocytes (Callan 1986 ) and spermatocytes (for review, see Hackstein 1987).

\section{Nucleolus formation}

The nucleolus is a complex structure with multiple components that are produced elsewhere within the nucleus and in the cytoplasm (for review, see Goessens 1984). The studies presented here suggest that the ability to concentrate and organize these materials into a nucleolus (nucleolar organizing activity) is an intrinsic property of the rDNA repeat. The formation of a nucleolus may result from the rDNA sequences themselves binding key components. Alternatively, the rRNA products may be the primary determinants of nucleolus formation. In a variety of systems, synthesis of rRNA and not the mere presence of rDNA appears to be closely linked to nucleolus formation. Many organisms 
contain 'silent' $r$ RNA genes that are not associated with a nucleolus unless the function of the primary NOs is disrupted (Flavell and Martini 1982; Lima-de-Faria 1983). Nucleolar dominance has been observed in many interspecies crosses and, in Xenopus, has been correlated with the transcriptional competence of the rRNA genes (Reeder 1984). In addition, nucleoli regress when cells are treated with inhibitors of rRNA synthesis (Simard et al. 1974) and during the mitosis (M) phase of the cell cycle, when transcription has ceased (de la Torre and Gimenez-Martin 1982). These results indicate that rRNA synthesis is essential to, but not necessarily a primary determinant of, nucleolus formation.

Nucleoli may be 'self-assembled' around the products of actively transcribing rRNA genes, using a cascade of molecular interactions analogous to those demonstrated for the assembly of the tobacco mosaic virus (FraenkelConrat and Williams 1955; Butler and Klug 1978; Klug 1979|. For example, rRNA could bind processing enzymes; processed rRNAs and/or the processing enzymes could then interact with 5S RNA and ribosomal proteins. Escherichia coli ribosomal subunits can be reconstituted in vitro from purified constituents (Nomura 1973, 1977; Whitman 1983); thus, in vivo self-assembly of an important component of the nucleolus, the ribosome, is possible in prokaryotes and perhaps eukaryotes as well. Alternatively, nucleolar components could aggregate independently of the NO in prepackaged 'modules' (i.e., prenucleolar bodies), which then accumulate at the sites of rRNA synthesis (Ochs et al. 1985).

A more detailed study of the role rDNA plays in nucleolus formation is necessary to elucidate the mechanisms responsible for the assembly of the nucleolus. True self-assembly can only be directly tested in vitro using purified components. Nevertheless, P-elementmediated transformation of altered rRNA genes in Drosophila and an analysis of their ability to form a nucleolus at ectopic locations provide a methodology for identifying the sequences within the rDNA that are essential to nucleolus formation. Of special interest would be the behavior of point mutations that block rRNA synthesis or processing and of deletions of the $18 \mathrm{~S}$ and/or $28 \mathrm{~S}$ transcription units.

\section{Materials and methods}

Drosophila strains and culture

Flies were grown on standard corn meal/agar media (Lewis 1960 ) at 18 or $25^{\circ} \mathrm{C}$. Both $r y^{42}$ and $r y^{506}$ (provided by A. Spradling and G. Rubin) exhibit a severe $r y^{-}$phenotype. The balancer stocks used for chromosomal mapping of the $r y^{+}$inserts, y $s n^{3}$ cor-36/FM6; ry ${ }^{506}, \mathrm{Sco} / \mathrm{Cy} ; \mathrm{ry}^{506} / \mathrm{TM} 3, \mathrm{Sb} r \mathrm{y}^{R K}$ and $r \mathrm{ry}^{506} ; \mathrm{ci}^{D}$, were generously donated by B. Wakimoto. $b b^{\text {sev }}$ and $b b^{\text {rllo }}$ were donated by S. Hawley and K. Tartof, respectively. All other strains and mutations are as described in Lindsley and Grell (1968) or Lindsley and Zimm (1985, 1986, 1987).

\section{Plasmid constructions}

$\mathrm{P}($ rib,ry $) 7$ was constructed by subcloning a $13.2-\mathrm{kb}$ NruI-BalI fragment from pKB 326 (Long et al. 1981; M. Rebbert and I.
Dawid, unpubl.) and into the HpaI site of Carnegie 20 (Car 20; Rubin and Spradling 1983). The NruI-Ball fragment contains a single rRNA gene plus $\sim 750 \mathrm{bp}$ of $\mathrm{pBR}$ and $\sim 450 \mathrm{bp}$ of $\lambda$ sequences adjacent to the $5^{\prime}$ and $3^{\prime}$ spacers, respectively [see Fig. 1 for a map of the integrated form of p(rib,ry)7]. Blunt-end ligations were optimized by using a PEG ligation protocol (Zimmerman and Pheiffer 1983). Enzymes were purchased from Bethesda Research Labs, New England Biolabs, U.S. Biochemicals, and Boeringer-Mannheim.

\section{Plasmid Preparation}

Plasmids were grown in L-broth (Maniatis et al. 1982) supplemented with ampicillin; $50 \mu \mathrm{g} / \mathrm{ml}$ of ampicillin was used for the smaller plasmids, whereas $25 \mu \mathrm{g} / \mathrm{ml}$ was used for growing larger plasmids to minimize selection for smaller, deleted forms. Plasmids were then prepared using a standard detergent lysis method (Clewell and Helinski 1970), and supercoiled forms were purified by two successive $\mathrm{CsCl}$ gradients. With the larger plasmids, gentle agitation was used throughout preparation to minimize breakage.

\section{Injections and chromosomal mapping of inserts}

Embryos homozygous for $r y^{42}$ or $r y^{506}$ were injected with buffer ( $5 \mathrm{mM} \mathrm{KCl}, 0.1 \mathrm{mM} \mathrm{NaH} \mathrm{PO}_{4}$ ) that contained $100 \mathrm{ng} / \mu \mathrm{l}$ of the P-element helper plasmid pП25.7wc (Karess and Rubin 1984), plus equimolar amounts of p(rib,ry)7, according to the protocol of Rubin and Spradling (1982). Injected animals (Generation Zero, or G0) were raised, and viable adults were crossed to $r y^{42}$ or $r y^{506}$ animals. The G1 progeny from these crosses were scored for $\mathrm{ry}^{+}$germ-line transformants, as outlined in Spradling and Rubin (1982). One $r y^{+}$transformant, which arose from a $\mathrm{p}(\mathrm{rib}, \mathrm{ry}) 7$ injectee, was recovered after screening the progeny from a total of 434 fertile G0 animals. The low frequency of transformation observed for the $p$ (rib,ry) vectors is dependent on the presence of the rDNA and is associated with a high frequency of plasmid rearrangement after injection (for a detailed analysis, see Karpen 1987; G.H. Karpen and C.D. Laird, in prep.).

The site of $p(r i b, r y) 7$ insertion in the original transformed line was mapped by crossing $\mathrm{ry}^{+} \mathrm{G} 1$ or $\mathrm{G} 2$ animals to the different $r y^{506}$ balancer stocks (see Drosophila strains and culture, above) and then crossing $\mathrm{ry}^{+}$-balancer $\mathrm{F} 1$ males and virgin females inter se. Complete segregation of the $\mathrm{ry}^{+}$marker from the chromosome 2 balancer $(C y)$ indicated that the insert was present on its homolog. The $r y^{+}$insert was maintained in a heterozygous line (homozygotes were not viable). Southern analysis of genomic DNA isolated from this line indicated that a single rib,ry insert was present. The structure of the P-element termini, $r y^{+}$, and rDNA sequences appeared identical to those in the original p(rib,ry)7 plasmid (Karpen 1987 and G. Karpen, unpubl.). Thus, no detectable rearrangements occurred during transformation. In situ hybridization to salivary gland polytene chromosome DNA, using rosy ${ }^{+}$sequences as a probe, indicated that the insert was located at band 23E (Karpen 1987). The in situ hybridization analysis also indicated that the insert was within a large paracentric inversion on chromosome arm $2 L$ (visible in Fig. 4d), which may be responsible for the homozygous lethality. This line was designated [rib7](23E), according to the convention of Lindsley and Zimm (1985). The number and letter following [rib7] in the name of the line [i.e., [rib7](23E)] and in genotype designations [i.e., [rib7](23E) ry ${ }^{+/}$ $\left.\mathrm{ScO} ; \mathrm{ry}^{506}\right]$ indicates the cytogenetic location of the inserted sequences, according to the salivary gland polytene chromosome map (Lefevre 1976). 


\section{Remobilization of inserts}

Additional transformed lines were generated by injecting [rib7]|23E $/ \mathrm{ry}^{+} / \mathrm{ScO}$; ry ${ }^{506}$ embryos with the P-element helper plasmid pП25.7wc (100 ng/ $\mu \mathrm{l}$ in injection buffer). The segregation of the $\mathrm{ry}^{+}$and Sco markers was monitored in subsequent generations to identify new transposition events (referred to as 'remobilants'). G0 adults were crossed individually to $\mathrm{Sco} / \mathrm{Cy}$; $r y^{506}$ animals, and all Gl progeny that were ry ${ }^{+}, \mathrm{Sco}$, and $\mathrm{Cy}$ in phenotype were further tested for the presence of a remobilized insert by following the chromosomal mapping scheme described in the preceding section. Also, $\mathrm{ry}^{+} / \mathrm{Sco}$ and $\mathrm{ry}^{+} / \mathrm{Cy} \mathrm{Gl}$ progeny were crossed en masse, and G2 progeny displaying the $\mathrm{ry}^{+}, \mathrm{Sco}$, and $\mathrm{Cy}$ phenotypes were tested further for the presence of a remobilized $\mathrm{ry}^{+}$insert. In contrast to the low frequency of initial transformation, remobilization of the rib,ry insert occurred with a high frequency; $18 \%$ of the fertile G0 $(n=55)$ yielded one or more remobilant progeny $\left(\mathrm{ry}^{+}\right.$, Sco, and Cy G1 or G2 progeny). A small number (16) of uninjected [rib7] $(23 \mathrm{E}) \mathrm{ry}^{+} / \mathrm{ScO}$; $\mathrm{ry}^{506}$ controls were crossed in the same manner and yielded no remobilants, indicating that mobilization of the $\mathrm{ry}^{+}$marker was mediated by the injected $\mathrm{P}$ elements. Lines with a $r y^{+}$marker mapping to chromosomes $X, 3$, or 4 were then analyzed for insert number, location, and integrity, using Southern analysis and in situ hybridization to polytene chromosomes (Karpen 1987). Southern analysis of genomic DNA from these stocks indicated that the remobilized rib,ry inserts were present in single copy and were not rearranged (Karpen 1987; G. Karpen, unpubl.). Although most of the eight inserts were present in euchromatic regions (1A, 23E, 68BC, $88 \mathrm{~B}, 94 \mathrm{~B}$ ), two of the inserts were localized to regions near the euchromatin/heterochromatin boundaries of chromosomes $X$ and 3 (cytogenetic intervals 20 and 80 ) and one was inserted into a site of 'intercalary heterochromatin' (56EF).

\section{In situ hybridization to RNA}

Chromosome squashes Salivary gland polytene chromosome squashes were prepared as described for DNA hybridizations, with the following modifications. Dissected glands were transferred to a drop $(\sim 15 \mu \mathrm{l})$ of $45 \%$ acetic acid on a siliconized coverslip and fixed in acetic acid for no more than $2 \mathrm{~min}$, to reduce the possibility of DNA denaturation. A minimum of tapping was used to avoid pulverizing the nucleolus.

RNA probe preparation Tritiated ETS-C and ETS-NC strand rRNA probes were generated via $\mathrm{T} 7$ (U.S. Biochemicals) and SP6 polymerase (NEN) catalyzed transcription reactions, using linearized plasmid pGEM-155A-ETS or pGEM130. pGEM-155A-ETS contains a 900-bp HpaI-SstII portion of the ETS inserted into the polylinker of pGEM1 (Promega Biotec). pGEM130 contains a $3-\mathrm{kb}$ SmaI fragment consisting of the $3^{\prime}$ end of the $18 \mathrm{~S}$ sequences, the entire internal transcribed spacer (ITS), and the $5^{\prime}$ end of the $28 \mathrm{~S}$ sequences, inserted in the polylinker of pGEM1. UTP and CTP labeled with ${ }^{3} \mathrm{H}$ were incorporated without the presence of cold UTP or CTP, using reaction conditions similar to those described previously (Cox et al. 1984). After 1-1.5 hr, RNase-free DNase (RQ1 DNase, Promega Biotec) was added directly to the reaction to remove the template. The reactions were terminated by the addition of $50 \mu \mathrm{g}$ tRNA and enough stop buffer $(0.1 \%$ SDS, $0.2 \mathrm{M} \mathrm{NaCl}, 10 \mathrm{mM}$ $\mathrm{Na}_{2}$ EDTA) to reach $100 \mu \mathrm{l}$ total. Probes were purified by extraction with one-half volume phenol, and P-60 column separation (Biogel) in $0.1 \times$ TE (Maniatis et al. 1982). Probe length was assessed using autoradiography of dried formaldehyde-agarose gels (Maniatis et al. 1982). Full-length probes were hydrolyzed to a size appropriate for in situ hybridization $(\sim 150 \mathrm{bp})$ by boiling for $1 \mathrm{hr}$ in $1 \times$ hydrolysis buffer ( $30 \mathrm{~mm}$ Tris-base, 100 mM NaCl, $1 \mathrm{mM} \mathrm{Na} 2$ EDTA), as described by Henikoff and Meselson (1977).

Hybridization For hybridization to RNA, it was necessary to omit the RNase pretreatment and denaturation steps used for in situ hybridization to chromosomal DNA (Gall and Pardue 1971). Slides were pretreated with acetic anhydride prior to hybridization (Cox et al. 1984). Hybridization and washes were modified slightly from the protocols described in Cox et al. (1984), as follows. Proteinase K pretreatment was not done, and either coverslips were sealed with rubber cement or slides were immersed in mineral oil. Each slide was hybridized overnight at $50^{\circ} \mathrm{C}$, with $2.5 \times 10^{5} \mathrm{cpm}$ of probe in $10 \mu \mathrm{l}$ hybridization buffer. After treatment with RNase A $[20 \mu \mathrm{g} / \mathrm{ml}$ in $0.5 \mathrm{M} \mathrm{NaCl}, 0.01 \mathrm{M}$ Tris ( $\mathrm{pH} 8.0$ ); $37^{\circ} \mathrm{C} ; 30 \mathrm{~min}$ ], slides were rinsed in buffer $\left[0.5 \mathrm{M} \mathrm{NaCl}, 0.01 \mathrm{M}\right.$ Tris $\left.(\mathrm{pH} 8.0) ; 37^{\circ} \mathrm{C} ; 30 \mathrm{~min}\right]$ and then washed three to four times for $15 \mathrm{~min}$ in $2 \times \mathrm{SSC}$ at $60^{\circ} \mathrm{C}$ and three times for $15 \mathrm{~min}$ in $0.1 \times \mathrm{SSC}$ at $60^{\circ} \mathrm{C}$. Slides were dehydrated twice for $5 \mathrm{~min}$ in $70 \%$ ethanol and twice for $5 \mathrm{~min}$ in 95\% ethanol before being air-dried. Slide dipping and autoradiography were carried out according to the protocol of Gall and Pardue (1971). Exposures were usually for $11-12$ days at $4^{\circ} \mathrm{C}$. All data and photographs are from females, unless noted otherwise.

\section{$\left[{ }^{3}\right.$ H]uridine incorporation}

Incorporation of $\left[{ }^{3} \mathrm{H}\right]$ uridine (Mukherjee and Beermann 1965) into heat-shocked salivary gland chromosomes used a modification (E. Jaffe, pers. comm.) of the protocol of Pierce and Lucchesi (1980). Wandering-stage third-instar larvae were heatshocked for $20 \mathrm{~min}$ at $37^{\circ} \mathrm{C}$. Salivary glands were dissected out in Ringer's solution (Schubiger 1971), preheated to $37^{\circ} \mathrm{C}$. The glands were transferred to $5-10 \mu \mathrm{l}$ of Ringer's containing [ ${ }^{3} \mathrm{H}$ ] uridine (final concentration, $40 \mu \mathrm{Ci} / \mathrm{ml}$; supplied at $1 \mathrm{mCi}$ / $\mathrm{ml}$ by $\mathrm{NEN}$ ), on a siliconized coverslip, on a $37^{\circ} \mathrm{C}$ heating block, for 3-5 min. Glands were then fixed for $5 \mathrm{~min}$ in watch glass dishes containing a 3:1 mixture of ethanol and acetic acid and transferred to $15 \mu \mathrm{l}$ of $45 \%$ acetic acid on a siliconized coverslip. Chromosome squashes were carried out as described by Atherton and Gall (1972). Slides were dipped in emulsion, exposed for 3-7 days at $4^{\circ} \mathrm{C}$, developed, and stained with Giemsa, as described in Gall and Pardue (1971).

\section{Antibody staining of polytene chromosomes}

Salivary-gland chromosome squashes were prepared according to the $45 \%$ acetic acid method described in Saumweber et al. (1980). After rinsing in PBS (10 mM phosphate buffer, $145 \mathrm{~mm}$ $\mathrm{NaCl}, 0.01 \% \mathrm{NaN}_{3}$ l, the slides were incubated for $2-4 \mathrm{hr}$ with $100 \mathrm{ml}$ of the primary antibody diluted $1: 10,000$ in PBS. All incubations were done in a moist chamber at room temperature. The primary antibody was $\mathrm{Ajl}$, a monoclonal antibody isolated after injection of total nuclear proteins from the $D$. melanogaster embryonic cell line Kc into mice, which recognizes an unknown Drosophila nucleolar antigen (Saumweber 1980; Frasch et al. 1986). The Ajl antibody was graciously donated by H. Saumweber, through S. Zimmerman and E. Wieschaus. The slides were washed twice in PBS, for a total of 10 min, and incubated for $1-2 \mathrm{hr}$ with $100 \mathrm{ml}$ of the secondary antibody (biotin-conjugated goat anti-mouse, Vector Laboratories), diluted $1: 200$ in PBS. After two 5-min washes in PBS, slides were incubated for $1 / 2-1 \mathrm{hr}$, in the dark, with $100 \mu \mathrm{l}$ of a 
fluorescein-avidin conjugate (Avidin FCS, Vector Laboratories) diluted $1: 100$ in PBS. Slides were rinsed twice for 5 min each in PBS, and then mounted in $90 \%$ glycerol under a coverslip. Preparations were examined under Nomarski and phase optics, with and without epifluorescence, using a Nikon MicrophotFX.

\section{Rescue of bobbed mutant phenotypes}

Rib,ry integrants were assessed for their ability to rescue bobbed phenotypes in animals deficient for the endogenous rRNA genes. Animals containing a heteroallelic combination of bobbed alleles, bbsev (bobbed-severe) and bb ${ }^{\text {rl16 }}$ (bobbed-reduced-lethal 16) were analyzed for three phenotypes (lethality, eclosion delay, and abdominal etching; Ritossa 1976), in the presence and absence of a rib,ry insert at $1 \mathrm{~A}$. This allelic combination was chosen because the functional rDNA content of such animals appears to be close to the minimum number required for viability; the few $b b^{\text {sev }} / b b^{\text {rllo }}$ animals that do eclose display extreme abdominal etching and very reduced bristle size. $X$ chromosomes with both a rib,ry insert and either the $b b^{s e v}$ or $b b^{r 116}$ alleles were constructed as follows. [rib7] $(1 \mathrm{~A})$ was recombined with y ac $v f$ su(f) to produce [rib7]|(1A) $v f s u(f)$ which, in turn, was recombined with y mei-41 $b b^{\text {sev }}$ and $b b^{\text {rl15 }}$ chromosomes to yield the [rib7](1A)ry ${ }^{+} m e i-41 \quad b b^{\text {sev }}$ and $\left[\right.$ rib7] (1A) ry ${ }^{+} b b^{r 116}$ chromosomes used in these experiments. Control animals (with no insert) were made rosy ${ }^{+}$by crossing a third chromosome rosy ${ }^{+}$transformant into the $b b^{s e v}$ and $b b^{\text {rll }}$ stocks $\left\{\left[6 \Delta \mathrm{HS} \mid r y^{+}\right.\right.$, a transformant isolated after injection of a p(rib,ry) derivative deleted for all the rDNA; see Karpen 1987). This was necessary because $r y^{-}$was observed to enhance bobbed phenotypes in control experiments. Progeny were produced by the following crosses.

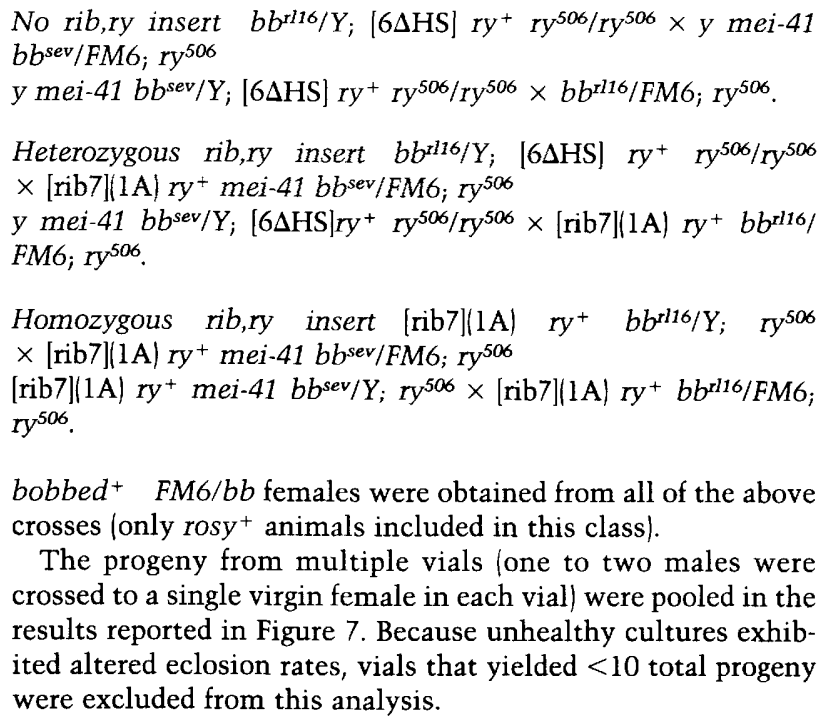

Homozygous rib,ry insert [rib7](1A) $\quad r y^{+} \quad b b^{r 116 / Y ;} \quad r y^{506}$ $\times\left[\right.$ rib7] $[1 \mathrm{~A}) \mathrm{ry}^{+}$mei-41 $\mathrm{bb}^{\text {sev }} /$ FM6; ry $\mathrm{rob}^{506}$

$[\mathrm{rib} 7](1 \mathrm{~A}) \mathrm{ry}^{+}$mei-41 bb $b^{\mathrm{sev}} / Y ; r y^{506} \times[\mathrm{rib} 7](1 \mathrm{~A}) \mathrm{ry}^{+} b b^{\text {rl16/FM6; }}$ ry 506 .

bobbed $^{+} \quad F M 6 / b b$ females were obtained from all of the above crosses (only rosy ${ }^{+}$animals included in this class).

The progeny from multiple vials (one to two males were crossed to a single virgin female in each vial) were pooled in the results reported in Figure 7. Because unhealthy cultures exhibited altered eclosion rates, vials that yielded $<10$ total progeny were excluded from this analysis.

\section{Acknowledgments}

We thank I. Dawid for generously providing us with the plasmid pKB326, A. Spradling and G. Rubin for sending the Carnegie vectors and $\mathrm{p} \Pi 25.7 \mathrm{wc}, \mathrm{B}$. Wakimoto for the rosy- balancer stocks, S. Hawley and $\mathrm{K}$. Tartof for providing us with the bobbed alleles, and H. Saumweber, S. Zimmerman, and E. Wieschaus for the Ajl antibody. We are grateful to Robert Devlin, Bruce Edgar, Scott Hawley, Steve Henikoff, Elizabeth Jaffe, Erik Jorgensen, Mary Lamb, Rebecca Nelson, Ron Reeder, Vicki Schweickart, Allan Spradling, John Tomkiel, John Tower, and Barbara Wakimoto for helpful discussions and critical comments on the manuscript. This work was supported by the National Institutes of Health (General Medical Sciences) and the National Science Foundation (Eukaryotic Genetics). G.K. was supported, in part, by the National Institutes of Health Training Program in Genetics General and Medical.

\section{References}

Ananiev, E.V. and V.A. Gvozdev. 1974. Changed pattern of transcription and replication in polytene chromosomes of Drosophila melanogaster resulting from eu-heterochromatin rearrangement. Chromosoma 45: 173-191.

Ananiev, E.V., V.E. Barsky, Y.V. Ilyin, and N.A. Churikov. 1981. Localization of nucleoli in Drosophila melanogaster polytene chromosomes. Chromosoma 81: 619-628.

Artavanis-Tsakonas, S., P. Schedl, C. Tschudi, V. Pirrotta, R. Steward, and W.J. Gehring. 1977. The 5S genes of Drosophila melanogaster. Cell 12: 1057-1067.

Atherton, D. and J. Gall. 1972. Salivary gland squashes for in situ nucleic acid hybridization studies. Dros. Inf. Serv. 49: $131-133$.

Babu, K.A. and R.S. Verma. 1985. Structural and functional aspects of nucleolar organizer regions (NORs) of human chromosomes. Int. Rev. Cytol. 94: 151-176.

Baker, S.M. and T. Platt. 1986. Pol I transcription: Which comes first, the end or the beginning? Cell 47: 839-840.

Baker, W.K. 1971. Evidence for position-effect suppression of the ribosomal RNA genes in Drosophila melanogaster. Proc. Natl. Acad. Sci. 68: 2472-2476.

Berns, M.W. 1973. Laser microirradiation of chromosomes. Cold Spring Harbor Symp. Quant. Biol. 38: 165-174.

Berns, M.W. and W.K. Cheng. 1971. Are chromosome secondary constrictions nucleolar organizers? Exp. Cell Res. 69: $185-192$.

Bridges, C.B. 1935. Salivary chromosome maps. I. Hered. 26: $60-64$.

Brown, D.D. and I.B. Dawid. 1968. Specific gene amplification in oocytes. Science 160: 272-280.

Butler, P.J.G. and A. Klug. 1978. The assembly of a virus. Sci. Am. 239(5): 52-59.

Callan, H.G. 1986. Lampbrush chromosomes. In Molecular biology, biochemistry and biophysics (ed M. Solioz), vol. 36, pp. 106-132, Springer-Verlag, New York.

Clewell, D.B. and D.R. Helinksi. 1970. Properties of a supercoiled deoxyribonucleic acid-protein relaxation complex and strand specificity of the relaxation event. Biochemistry 9: $4428-4440$.

Coen, E.S. and G.A. Dover. 1983. Unequal exchanges and the coevolution of $\mathrm{X}$ and $\mathrm{Y}$ rDNA arrays in Drosophila melanogaster. Cell 33: 849-855.

Cooper, K.W. 1959. Cytogenetic analysis of major heterochromatic elements (especially Xh and Y) in Drosophilia melanogaster, and the theory of 'heterochromatin.' Chromosoma 10: $535-588$.

Cox, K.H., D.V. DeLeon, L.M. Angerer, and R.C. Angerer. 1984. Detection of mRNAs in sea urchin embroys by in situ hybridization using asymmetric RNA probes. Dev. Biol. 101: 485-502.

Dawid, I.B. and M.L. Rebbert. 1986. Expression of ribosomal insertion in Drosophila: Sensitivity to intercalating drugs. Nucleic Acids Res. 14: 1267-1277.

Dawid, I.B., D.D. Brown, and R.H. Reeder. 1970. Composition and structure of chromosomal and amplified ribosomal DNAs of Xenopus laevis. J. Mol. Biol. 51: 341-360.

de la Torre, C. and G. Gimenez-Martin. 1982. The nucleolar 
cycle. In The nucleolus (ed. E.G. Jordan and C.A. Cullis), pp. 153-177. Cambridge University Press, Cambridge.

DeSalle, R. and A.R. Templeton. 1986. The molecular through ecological genetics of abnormal abdomen. III. Tissue-specific differential replication of ribosomal genes modulates the abnormal abdomen phenotype in Drosophila mercatorum. Genetics 112: 877-886.

Dhar, V.N., D.A. Miller, and O.J. Miller. 1985. Transcription of mouse rDNA and associated formation of the nucleolus organizer region after gene transfer and amplification in Chinese hamster cells. Mol. Cell. Biol. 5: 2943-2950.

Dover, G. 1982. Molecular drive: A cohesive model for species evolution. Nature 299: 111-117.

Durica, D.S. and H.M. Krider. 1978. Studies on the ribosomal RNA genes in interspecific Drosophila hybrids: II. Heterochromatic regions mediating nucleolar dominance. Genetics 89: 37-64.

Elion, E.A. and J.R. Warner. 1986. An RNA polymerase I enhancer in Saccharomyces cerevisiae. Mol. Cell. Biol. 6: $2089-2097$.

Endow, S.A. 1980. On ribosomal gene compensation in Drosophila. Cell 22: 149-155.

Endow, S.A. and D.M. Glover. 1979. Differential replication of ribosomal genes in polytene nuclei of Drosophila. Cell 17: 597-605.

Flavell, R.B. and G. Martini. 1982. The genetic control of nucleolus formation with special reference to common breadwheat. In The nucleolus (ed. E.G. Jordan and C.A. Cullis), pp. 113-128. Cambridge University Press, Cambridge.

Fraenkel-Conrat, H. and R.C. Williams. 1955. Reconstitution of active tobacco mosiac virus from its inactive protein and nucleic acid components. Proc. Natl. Acad. Sci. 41: 690698.

Franz, G. and W. Kunz. 1981. Intervening sequences in ribosomal RNA genes and bobbed phenotype in Drosophila hydei. Nature 292: 638-640.

Frasch, M., D.M. Glover, and H. Saumweber. 1986. Nuclear antigens follow different pathways into daughter nuclei during mitosis in early Drosophila embryos. J. Cell Sci. 82: 155172.

Frenster, J.H. 1974. Ultrastructure and function of heterochromatin and euchromatin. In The cell nucleus (ed. H. Busch), vol. I, pp. 565-580. Academic Press, New York.

Gall, J.G. and M.L. Pardue. 1971. Nucleic acid hybridization in cytological preparations. Methods Enzymol. 21: 470-480.

Givens, J.F. and R.L. Phillips. 1976. The nucleolus organizer region of maize (Zea mays L.). Chromosoma 57: 103-117.

Glover, D.M. 1981. The rDNA of Drosophila melanogaster. Cell 26: 297-298.

Goessens, G. 1984. Nucleolar structure. Int. Rev. Cytol. 87: $107-158$.

Grimaldi, G. and P.P. DiNocera. 1986. Transient expression of Drosophila melanogaster rDNA promoter into cultured Drosophila cells. Nucleic Acids Res. 14: 6417-6432.

Grummt, I., A. Kuhn, I. Bartsch, and H. Rosenbauer. 1986. A transcription terminator located upstream of the mouse rDNA initiation site affects rRNA synthesis. Cell 47: 901911.

Hackstein, J.H.P. 1987. Spermatogenesis in Drosophila. In Spermatogenesis: Genetic aspects (ed. W. Hennig), pp. 63-116. Springer-Verlag, New York.

Hammond, M.P. and C.D. Laird. 1985. Control of DNA replication and spatial distribution of defined DNA sequences in salivary glands of Drosophila melanogaster. Chromosoma 91: 279-286.

Hannah-Alava, A. 1971. Cytogenetics of nucleolus-transposi- tions in Drosophila melanogaster. Mol. Gen. Genet. 113: 191-203.

Henderson, S. and B. Sollner-Webb. 1986. A transcriptional terminator is a novel element of the promoter of the mouse ribosomal RNA gene. Cell 47: 891-900.

Henikoff, S. and M. Meselson. 1977. Transcription at two heat shock loci in Drosophila. Cell 12: 441-451.

Hill, R.J. and F. Watt. 1977. 'Native' salivary chromosomes of Drosophila melanogaster. Cold Spring Harbor Symp. Quant. Biol. 42: 859-865.

Hilliker, A.J. 1980. The genetic analysis of $D$. melanogaster heterochromatin. Cell 21: 607-619.

Hilliker, A.J. and R. Appels. 1982. Pleiotropic effects associated with the deletion of heterochromatin surrounding rDNA on the X chromosome of Drosophila. Chromosoma 86: 469 490.

Hilliker, A.J., R. Appels, and A. Schalet. 1980. The genetic analysis of D. melanogaster heterochromatin. Cell 21: 607-619.

Hochstrasser, M. and J.W. Sedat. 1987. Three-dimensional organization of Drosophila melanogaster interphase nuclei. II. Chromosome spatial organization and gene regulation. I. Cell Biol. 104: 1471-1483.

Jamrich, M. and O.L. Miller, Jr. 1984. The rare transcripts of interrupted rRNA genes in Drosophila melanogaster are processsed or degraded during synthesis. EMBO /. 3: 15411545.

Karess, R.E. and G.M. Rubin. 1984. Analysis of P transposable element functions in Drosophila. Cell 38: 135-146.

Karpen, G.H. 1987. The relationship between organization and function of ribosomal genes in Drosophila melanogaster. $\mathrm{Ph} . \mathrm{D}$. dissertation, University of Washington, Seattle, Washington.

Klug, A. 1979. The assembly of tobacco mosaic virus: Structure and specificity. Harvey Lect. 74: 141-172.

Kunz, W., C. Grimm, and G. Franz. 1982. Amplification and synthesis of rDNA: Drosophila. In The cell nucleus (ed. Busch and L. Rothblum), vol. XII, pp. 155-185. Academic Press, New York.

Labhart, P. and R.H. Reeder. 1986. Characterization of three sites of $3^{\prime}$ end formation in the Xenopus ribosomal gene spacer. Cell 45: 431-443.

Laird, C.D., L.E. Wilkinson, V.E. Foe, and W.Y. Chooi. 1976. Analysis of chromatin-associated fiber arrays. Chromosoma 58: 169-192.

Lakhotia, S.C. and J. Jacob. 1974. EM autoradiographic studies on polytene nuclei of Drosophila melanogaster. II. Organization and transcriptive activity of the chromocentre. Exp. Cell Res. 86: 253-263.

Larson, D.D., E.H. Blackburn, P.C. Yaeger, and E. Orias. 1986. Control of rDNA replication in Tetrahymena involves a cisacting upstream gene of a promoter element. Cell 47: 229240.

Lefevre G., Jr. 1976. A photographic representation and interpretation of the polytene chromosomes of Drosophila melanogaster salivary glands. In The genetics and biology of Drosophila (ed. M. Ashburner and E. Novitski), vol. 1a, pp. 31-66. Academic Press, New York.

Lewis, E.B. 1960. A new standard food medium. Dros. Inf. Serv. 34: $117-118$.

Lima-de-Faria, A. 1976. The chromosome field. I. Prediction of the location of ribosomal genes. Hereditas 83: 1-22.

1983. Molecular evolution and organization of the chromosome, pp. 329-418. Elsevier Science Publishers, Amsterdam.

Lindsley, D.L. and E.H. Grell. 1968. Genetic variations of Drosophila melanogaster. Carnegie Inst. Wash. Publ. 627. 
Lindsley, D.L. and G. Zimm. 1985, The genome of Drosophila melanogaster (progress report). Dros. Inf. Serv. 62.

- 1986. The genome of Drosophila melanogaster (progress report). Dros. Inf. Serv. 64.

- 1987. The genome of Drosophila melanogaster (progress report). Dros. Inf. Serv. 65.

Long, E.O. and I.B. Dawid. 1979. Expression of ribosomal DNA insertions in Drosophila melanogaster. Cell 18: 1185-1196.

- 1980. Repeated genes in eucaryotes. Annu. Rev. Biochem. 49: 727-764.

Long, E.O., M.L. Rebbert, and I.B. Dawid. 1981. Nucleotide sequence of the initiation site for ribosomal RNA transcription in Drosophila melanogaster: Comparison of genes with and without insertions. Proc. Natl. Acad. Sci. 78: 15131517.

Macgregor, H.C. 1982. Ways of amplifying ribosomal genes. In The nucleolus (ed. E.G. Jordan and C.A. Cullis), pp. 129-151. Cambridge University Press, Cambridge.

Maeda, N. and O. Smithies. 1986. The evolution of multigene families: Human haptoglobin genes. Annu. Rev. Genet. 20: $81-108$.

Maniatis, T., E.F. Fritsch, and J. Sambrook. 1982. Molecular cloning: A laboratory manual. Cold Spring Harbor Laboratory, Cold Spring Harbor, New York.

McClintock, B. 1934. The relationship of a particular chromosomal element to the development of the nucleoli of Zea mays. Z. Zellforsch. 21: 294-328.

McKee, B.M. and D.L. Lindsley. 1987. Inseparability of $X$-heterochromatic functions responsible for $X: Y$ pairing, meiotic drive, and male fertility in Drosophila melanogaster. Genetics 116: 399-407.

McStay, B. and R.H. Reeder. 1986. A termination site for Xenopus RNA polymerase I also acts as an element of an adjacent promoter. Cell 47: 913-920.

Miller, O.L., Jr., and B.R. Beatty. 1969. Visualization of nucleolar genes. Science 164: 955-957.

Mukheriee, A.S. and W. Beermann. 1965. Synthesis of RNA by the X-chromosomes of Drosophila melanogaster and the problem of dosage compensation. Nature 207: 785-786.

Muller, H.J. and T.S. Painter. 1932. The differentiation of the sex chromosomes of Drosophila into genetically active and inert regions. Z. Abstam. Vererbungsl. 62: 316-365.

Nix, C.E. 1973. Suppression of transcription of the ribosomal DNA genes in a structurally rearranged chromosome. Biochem. Genet. 10: 1-12.

Nomura, M. 1973. Assembly of bacterial ribosomes. Science 179: $864-873$.

1977. Some remarks on recent studies on the assembly of ribosomes. In Nucleic acid-Protein recognition (ed. H.J. Vogel), pp. 443-467. Academic Press, New York.

Ochs, R.L., M.A. Lischwe, E. Shen, R.E. Carroll, and H. Busch. 1985. Nucleologenesis: Composition and fate of prenucleolar bodies. Chromosoma 92: 330-336.

Pardue, M.L. and J.G. Gall. 1972. Molecular cytogenetics. In Molecular cytogenetics and developmental biology (ed. M. Sussman), pp. 65-99. Prentice Hall, Englewood Cliffs, New Jersey.

Pardue, M.L., S.A. Gerbi, R.A. Eckhardt, and J.G. Gall. 1970. Cytological localization of DNA complementary to ribosomal RNA in polytene chromosomes of Diptera. Chromosoma 29: 268-290.

Petes, T.D. 1980. Unequal meiotic recombination within tandem arrays of yeast ribosomal DNA genes. Cell 19: 765774.

Pierce, D.A. and J.C. Lucchesi. 1980. Dosage compensation of X-linked heat-shock puffs in Drosophila pseudoobscura.
Chromosoma 76: 245-254.

Reeder, R.H. 1984. Enhancers and ribosomal gene spacers. Cell 38: 349-351.

Reeder, R.H., P. Labhart, and B. McStay. 1987. Processing and termination of RNA polymerase I transcripts. Bioessays 6: $108-112$.

Ritossa, F.M. 1964. Behavior of RNA and DNA synthesis at the puff level in salivary gland chromosomes of Drosophila. Exp. Cell Res. 36: 515-523.

. 1976. The bobbed locus. In The genetics and biology of Drosophila (ed. M. Ashburner and E. Novitski), vol. lb, pp. 801-846. Academic Press, New York.

Ritossa, F.M. and S. Spiegelman. 1965. Localization of DNA complementary to ribosomal RNA in the nucleolus organizer region of Drosophila melanogaster. Proc. Natl. Acad. Sci. 53: 737-745.

Roeder, R. 1976. Eucaryotic nuclear RNA polymerases. In RNA polymerase (ed. R. Losick and $M$. Chamberlin), pp. 258-329. Cold Spring Harbor Laboratory, Cold Spring Harbor, New York.

Rubin, G.M. and A.C. Spradling. 1982. Genetic transformation of Drosophila with transposable element vectors. Science 218: 348-353.

-1983. Vectors for P element-mediated gene transfer in Drosophila. Nucleic Acids Res. 11: 6341-6351.

Saumweber, H. 1980. Monoklonale Antikörper gegen Kernproteine von Drosophila melanogaster. Ph.D. dissertation, Eberhard-Karls-Universität, Tübingen, Federal Republic of Germany.

Saumweber, H., P. Symmons, R. Kabisch, H. Will, and F. Bonhoeffer. 1980. Monoclonal antibodies against chromosomal proteins of Drosophila melanogaster: Establishment of antibody producing cell lines and partial characterization of corresponding antigens. Chromosoma 80: 253-275.

Schalet, A. 1969. Exchanges at the bobbed locus in Drosophila melanogaster. Genetics 63: 133-153.

Schubiger, G. 1971. Regeneration, duplication and transdetermination in fragments of the leg disc of Drosophila melanogaster. Dev. Biology 26: 277-295.

Simard, R., Y. Langelier, R. Mandeville, N. Maestracci, and A. Royal. 1974. Inhibitors as tools in elucidating the structure and function of the nucleus. In The cell nucleus (ed. $\mathrm{H}$. Busch|, vol. III, pp. 447-487. Academic Press, New York.

Simon, J.A., C.A. Sutton, and J.T. Lis. 1985a. Localization and expression of transformed DNA sequences within heat shock puffs of Drosophila melanogaster. Chromosoma 93: 26-30.

Simon, J.A., C.A. Sutton, R.B. Lobell, R.L. Glaser, and J.T. Lis. 1985b. Determinants of heat shock-induced chromosome puffing. Cell 40: 805-817.

Smetana, K. and H. Busch. 1974. The nucleolus and nucleolar DNA. In The cell nucleus (ed. H. Busch), vol. I, pp. 73-147. Academic Press, New York.

Sollner-Webb, B. and J. Tower. 1986. Transcription of cloned eukaryotic ribosomal RNA genes. Annu. Rev. Biochem. 55: $801-830$.

Spear, B.B. and J.G. Gall. 1973. Independent control of ribosomal gene replication in polytene chromosomes of Drosophila melanogaster. Proc. Natl. Acad. Sci. 70: 1359-1363.

Spradling, A.C. and G.M. Rubin. 1982. Transposition of cloned P elements in Drosophila germline chromosomes. Science 218: $341-347$.

Szostak, J.W. and R. Wu. 1980. Unequal crossing over in the ribosomal DNA of Saccharomyces cerevisiae. Nature 284: $426-430$

Tautz, D. and G.A. Dover. 1986. Transcription of the tandem 
array of ribosomal DNA in Drosophila melanogaster does not terminate at any fixed point. EMBO /. 5: 1267-1273.

Templeton, A.R. and M.A. Rankin. 1978. Genetic revolutions and the control of insect populations. In The screw-worm problem (ed. R.H. Richardson), pp. 83-111. University of Texas Press, Austin.

Vance, V.B., E.A. Thompson, and L.H. Bowman. 1985. Transfection of mouse ribosomal DNA into rat cells: Faithful transcription and processing. Nucleic Acids Res. 13: 74997513.

Viinikka, Y., A. Hannah-Alava, and P. Arajarvi. 1971. A reinvestigation of the nucleolus-organizing regions in the salivary gland nuclei of Drosophila melanogaster. Chromosoma 36: 34-45.

Voelkel-Meiman, K., R.L. Keil, and G.S. Roeder. 1987. Recombination-stimulating sequences in yeast ribosomal DNA correspond to sequences regulating transcription by RNA polymerase I. Cell 48: 1071-1079.

Whitman, H.G. 1983. Components of bacterial ribosomes. Annu. Rev. Biochem. 51: 155-184.

Zimmerman, S.B. and B.H. Pheiffer. 1983. Macromolecular crowding allows blunt-end ligation by DNA ligases from rat liver or Escherichia coli. Proc. Natl. Acad. Sci. 80: 58525856. 


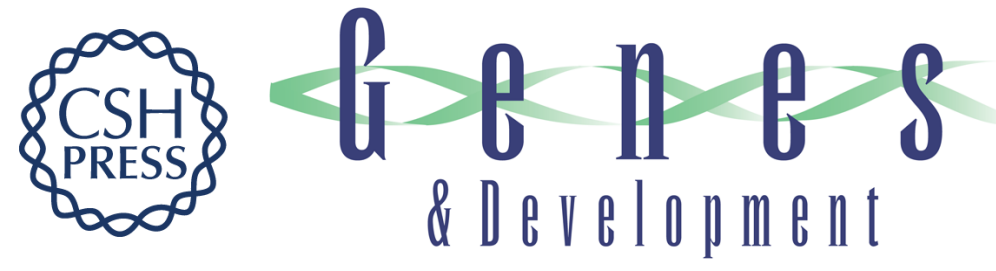

\section{A Drosophila rRNA gene located in euchromatin is active in transcription and nucleolus formation.}

G H Karpen, J E Schaefer and C D Laird

Genes Dev. 1988, 2:

Access the most recent version at doi:10.1101/gad.2.12b.1745

References This article cites 89 articles, 19 of which can be accessed free at:

http://genesdev.cshlp.org/content/2/12b/1745.full.html\#ref-list-1

License

Email Alerting

Service

Receive free email alerts when new articles cite this article - sign up in the box at the top right corner of the article or click here.

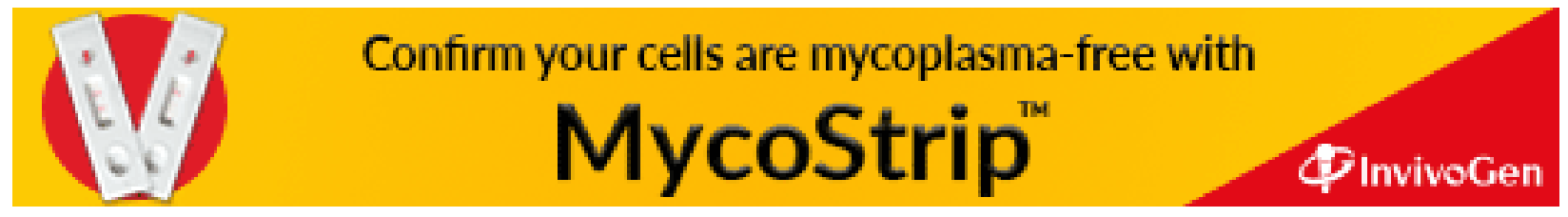

